\title{
REVIEW OF POTENTIAL EGS SITES AND POSSIBLE EGS DEMONSTRATION SCENARIOS
}

\author{
for \\ U.S. Department of Energy \\ Washington, DC
}

via.

Princeton Economic Research, Inc.

Rockville, MD

by

GeothermEx, Inc.

Richmond, California

SEPTEMBER 1999 


\section{DISCLAIMER}

This report was prepared as an account of work sponsored by an agency of the United States Government. Neither the United States Government nor any agency Thereof, nor any of their employees, makes any warranty, express or implied, or assumes any legal liability or responsibility for the accuracy, completeness, or usefulness of any information, apparatus, product, or process disclosed, or represents that its use would not infringe privately owned rights. Reference herein to any specific commercial product, process, or service by trade name, trademark, manufacturer, or otherwise does not necessarily constitute or imply its endorsement, recommendation, or favoring by the United States Government or any agency thereof. The views and opinions of authors expressed herein do not necessarily state or reflect those of the United States Government or any agency thereof. 


\section{DISCLAIMER}

Portions of this document may be illegible in electronic image products. Images are produced from the best available original document. 


\section{CONTENTS}

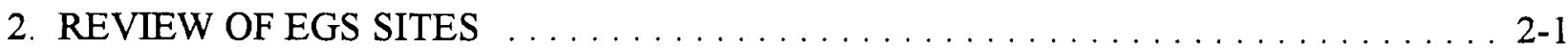

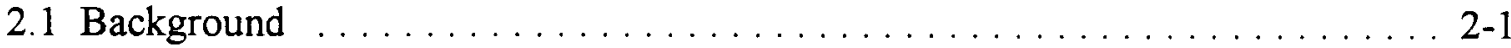

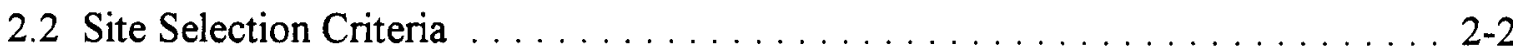

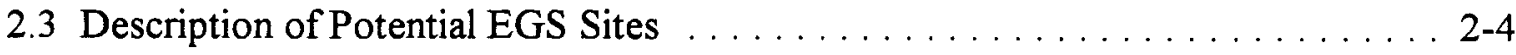

2.3.1 Introduction ................................ 2-4

2.3 .2 Coso, California . . . . . . . . . . . . . . . . . . . 2-7

2.3.3 East Mesa, California . . . . . . . . . . . . . . . . . . 2-8

2.3.4 The Geysers, California . . . . . . . . . . . . . . . . . . . . . . . . . . . 2 2-9

2.3.5 Heber, California . . . . . . . . . . . . . . . . . . . . . . . 2-12

2.3.6 Glass Mountain, California . . . . . . . . . . . . . . . . . . . . 2-13

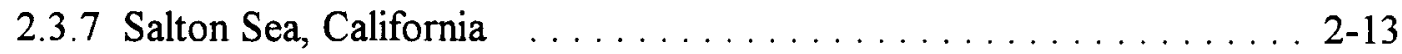

2.3.8 Puna, Hawaii . . . . . . . . . . . . . . . . . . . . . . . . 2-15

2.3.9 Bradys Hot Springs, Nevada . . . . . . . . . . . . . . . . . . 2-16

2.3.10 Desert Peak, Nevada . . . . . . . . . . . . . . . . . . . . . . . . . . 2-17

2.3.11 Dixie Valley, Nevada . . . . . . . . . . . . . . . . . . . . . . . . 2-18

2.3.12 Soda Lake, Nevada . . . . . . . . . . . . . . . . . . . . . . . . . 2 2-19

2.3.13 Steamboat, Nevada . . . . . . . . . . . . . . . . . . . . . 2-20

2.3.14 Stillwater, Nevada . . . . . . . . . . . . . . . . . . . . 2-21

2.3.15 Newberry, Oregon ......................... 2-22

2.3.16 Cove Fort, Utah ........................ 2-23

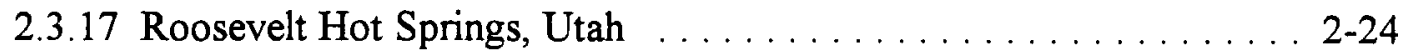

3. POSSIBLE EGS DEMONSTRATION SCENARIOS $\ldots \ldots \ldots \ldots \ldots \ldots \ldots \ldots$ 3-1

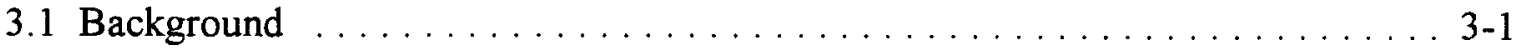

3.2 EGS Project Supplying Existing Geothermal Development . . . . . . . . . . 3-2

3.3 Separate EGS Facility Adjacent to Existing Geothermal Development . . . . . 3-5

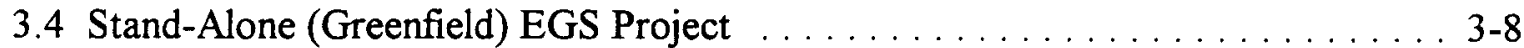


GeothermEx, InC. 5221 CENTRAL AVENUE, SUTTE 201 RICHMOND, CALIFORNIA 94804-5829

TELEPHONE: (510) 527-9876

FAX: (510) 527-8164

E-MAIL: MW@GEOTHERMEX.COM

4. REFERENCES

APPENDIX: Task Order Number DE-AT07-99ID670365 
TELEPHONE: (510) 527-9876

FAX: (510) 527-8164

E-MAIL: MW@GEOTHERMEX.COM

\section{ILLUSTRATIONS}

\section{Figures}

2.1 Location of geothermal projects in the western United States

2.2 Well location map, Coso geothermal field, California

2.3 Well location map, East Mesa geothermal field, California

2.4 Power areas and augmented injection projects at The Geysers geothermal field, California

2.5 Well location map, Heber geothermal field, California

2.6 Well location map, Glass Mountain geothermal field, California

2.7 Well location map, Salton Sea geothermal field, California

2.8 Well location map, Puna geothermal field, Hawaii

2.9 Well location map, Bradys Hot Springs geothermal field, Nevada

2.10 Well location map, Desert Peak geothermal field, Nevada

2.11 Well location map, Dixie Valley geothermal field, Nevada

2.12 Well location map, Soda Lake geothermal field, Nevada

2.13 Well location map, Steamboat geothermal field, Nevada

2.14 Well location map, Stillwater geothermal field, Nevada

2.15 Well location map, Newberry geothermal field, Oregon

2.16 Well location map, Cove Fort geothermal field, Utah

2.17 Well location map, Roosevelt geothermal field, Utah 


\section{INTRODUCTION}

Review of potential sites for Enhanced Geothermal Systems (EGS) and development of reference scenarios for EGS demonstration projects are two sub-tasks included in the FY1999 EGS

Research and Development (R\&D) Management Task (DOE Task Order Number DE-AT0799ID60365, included in the Appendix of this report). These sub-tasks are consistent with the EGS Strategic Plan, which includes milestones relating to EGS site selection (Milestone 4, to be completed in 2004) and development of a cost-shared, pilot-scale demonstration project (Milestone 5, to be completed in 2008). The purpose of the present work is to provide some reference points for discussing what type of EGS projects might be undertaken, where they might be located, and what the associated benefits are likely to be.

The review of potential EGS sites is presented in Chapter 2 of this report. It draws upon siteselection criteria (and potential project sites that were identified using those criteria) developed at a mini-workshop held at the April 1998 DOE Geothermal Program Review to discuss EGS R\&D issues. The criteria and the sites were the focus of a paper presented at the $4^{\text {th }}$ International Hot Dry Rock Forum in Strasbourg in September 1998 (Sass and Robertson-Tait, 1998). The selection criteria, project sites and possible EGS developments discussed in the workshop and paper are described in more detail herein. Input from geothermal operators is incorporated, and water availability and transmission-line access are emphasized.

The reference scenarios for EGS demonstration projects are presented in Chapter 3. Three alternative scenarios are discussed: 1) a stand-alone demonstration plant in an area with no existing geothermal development; 2) a separate generating facility adjacent to an existing geothermal development; and 3) an EGS project that supplies an existing geothermal power plant 
TELEPHONE: (510) 527.9876

FAX: (510) 527-8164

E-MAIL:MW@GEOTHERMEX.COM

with additional generating capacity. Furthermore, information potentially useful to DOE in framing solicitations and selecting projects for funding is discussed objectively.

Although defined as separate sub-tasks, the EGS site review and reference scenarios are closely related. The incremental approach to EGS development that has recently been adopted could logically be expected to yield proposals for studies that lead up to and include productionenhancement experiments in producing geothermal fields in the very near future. However, the strategic plan clearly calls for the development of a more comprehensive demonstration project that can generate up to perhaps $10 \mathrm{MW}$ (gross). It is anticipated that a series of small-scale experiments will define what realistically may be achieved in the near future, thus setting the stage for a successful pilot demonstration. This report continues the process of presenting information on EGS sites and experiments, and begins the process of defining what a demonstration project might be. 
TELEPHONE: (510) 527-9876

FAX: (510) 527-8164

E-MAIL:MW@GEOTHERMEX.COM

\section{REVIEW OF EGS SITES}

\subsection{Background}

Milestone 4 of the EGS Strategic Plan states:

"By 2004, select five prospective EGS sites and initiate projects in cooperation with industry to apply EGS methodologies and demonstrate increased energy recovery."

This milestone envisages that field experiments will be undertaken in either successful or unsuccessful wells, in areas within or adjacent to commercially developed hydrothermal fields. It has the goals of improving EGS technology and demonstrating EGS applications to increase energy recovery. The milestone goes on to state that a portfolio of potential EGS projects is to be developed to assist DOE in both accommodating as wide a range of EGS project types as possible, and prioritizing potential projects within each category.

The first step in this process was taken at the April 1998 DOE Geothermal Program Review, where an EGS "Mini-Workshop" was held to define future EGS projects. One of the focuses of the Mini-Workshop was to develop EGS site-selection criteria; these are presented in the following section. Section 2.3 presents information about the sites selected using these criteria, including the availability of water. The latter is important because it is likely that, as is presently being done at The Geysers, injection will be the mechanism of heat mining in both the short and long term. 
E-MAIL:MW@GEOTHERMEX.COM

\subsection{Site Selection Criteria}

The site-selection criteria were defined at the April 1998 DOE Geothermal Program Review by a group of about a dozen people from the geothermal industry, academia and the National Laboratories. All participants were aware of the focus on involving industry and the fiscal necessity of undertaking relatively small-scale experiments at the present time, which would both promote industry involvement and follow the incremental approach to EGS development suggested earlier to the Geothermal Energy Association by members of the geothermal industry. Criteria were developed with respect to the geothermal resource, the infrastructure that supports its development, and social issues. The most important social issue discussed was support not only from the geothermal industry but also from the public at large, so that the societal benefit can be realized.

The site-selection criteria related to infrastructure issues include:

- Proximity to a developed hydrothermal resource. This was considered to be one of the most important criteria, given the disparity between the cost of developing a new, standalone project and the price paid for electric power. When geothermal developers are paid between $\$ 0.02$ and $\$ 0.03$ per kilowatt-hour for power, it is obviously important to take advantage of existing infrastructure for access, generation and transmission of electricity. Transmission-cost requirements aside, it is well established that more than twice the current price is required to support the development of a new project supplied by a hydrothermal resource, and the cost to develop a new EGS project would be higher. However, at an existing facility, the additional power generated as a result of added heat recovery from an EGS project could be useful and marketable immediately. Therefore, all 
other criteria being equal, a project close to an existing facility would be preferable to one further away.

- The ability to use the fluid produced from the EGS to economic advantage. The EGS project could either sustain the ability of the power plant to meets its capacity requirements under existing power sales agreements, or increase power sales from the existing facility at competitive prices under the terms of a new agreement. Industry would favor EGS projects that sustain or increase output, reduce operating costs and/or increase the profitability of existing contracts.

The resource-related site selection criteria include:

- Low permeability or water content, or both. This follows the essential definition of EGS: systems in which permeability is too low for commercial exploitation by conventional methods and/or the reservoir is fluid-deficient. While fluid-deficiency is a natural consequence of low permeability, it could also be caused by long-term production. This implies fields that: 1) have low-permeability wells at the field margins; 2) have lowpermeability wells interspersed with commercial wells within the active production or injection areas; or 3) have become depleted as a result of exploitation.

- Water available for injection. As mentioned above, injection of water is likely to be the mechanism of heat recovery. Therefore, all other criteria being equal, a site with available water at a reasonable cost would be preferable.

- Existing wells available for EGS work. This criterion is the direct result of economic considerations. Because it is unlikely that initially limited $R \& D$ funds would support the 
drilling of new, dedicated EGS wells, it would be preferable to use existing wells for EGS work. These are likely to be tight or less productive wells that are unused for production or used for injection. The wells would need to be suitably completed or re-completed to safely perform the EGS work.

- A well characterized reservoir. The reservoir should be well characterized in terms of its geology and hydrology, boundaries, stress regime and permeability characteristics. This is an important criterion, because without it, no assessment of the results of the EGS work can be made. If some aspects of the reservoir are not well known, they would be appropriate subjects for investigation, as is presently being undertaken at the Dixie Valley field (characterization of the stress regime).

- An extensional stress regime. This would provide lower formation breakdown and fluid injection pressures than occur in compressional or strike-slip regimes. Fortunately, most known geothermal fields lie in regions of tectonic extension.

\subsection{Description of Potential EGS Sites}

\subsubsection{Introduction}

The most likely near-term candidates for EGS work will be geothermal fields with existing and sometimes under-utilized generation facilities. A second tier of candidates would consist of those for which wells have been drilled but no generation facilities currently exist. Figure 2.1 shows the location of potential candidates of both types in the western United States. A field operator could propose a program of EGS work and share the costs of the work with DOE. Jointly, DOE and the field operator would agree on methods to measure the benefit of enhancement, and the results 
TELEPHONE: (510) 527-9876

FAX: (510) 527-8164

E-MAIL: MW@GEOTHERMEX.COM

would be incorporated into a database of information that could be easily accessed by interested parties.

A preliminary review of sites with significant EGS potential has been performed, using publicly available information and additional data provided by field operators. Table 1 presents a list of these sites, prioritized based on a "yes-or-no" approach to the site criteria described above. The criterion of "proximity to a developed hydrothermal resource" was assessed based on the presence (or lack thereof) of an existing power plant and the availability of transmission-line capacity. The "prospect for economic advantage" was judged based on the current capacity and market potential of an existing plant to sell additional power. The sites were also evaluated based on the type of EGS work needed (stimulation of low permeability and/or mitigation of fluid deficiency). For both types of EGS work, the ranking considered the availability of suitable wells of opportunity and the availability of water. Finally, the sites were assessed according to whether they occurred in extensional stress regimes. Because all the sites considered have been studied fairly thoroughly, the criterion that the resource be "well-characterized" was not addressed separately. Projects satisfy an equal number of criteria are listed alphabetically.

The prioritization in Table 1 is qualitative and is based on a preliminary review. Any specific EGS proposal would need to be considered on its own merits, and fields with lower priorities in Table 1 might well prove to be attractive prospects.

The following sections provide summaries of publicly available information about all the sites considered. The sites are presented in alphabetical order (first by state, then by project name). For each site, the information has been reviewed with the current field operator for accuracy, and each operator has consented to the inclusion of the information in this report. To prepare a more 
TELEPHONE: (510) 527-9876

FAX: (510) 527-8164

E-MAIL:MW @ GEOTHERMEX.COM

thorough assessment of EGS potential in the United States, it would be useful to solicit further input from field operators on:

- wells of opportunity (location, depth, drilling history, completion information, present condition, and well logs);

- geologic conditions (formations to be encountered, state of stress);

- hydrologic conditions (permeability, injectivity, productivity, and hydraulic connectivity of various parts of the field, which may have been established by interference tests);

- EGS work that may have already been undertaken (particularly well stimulation);

- the field's general production and injection scheme (location of wells and production and injection rates);

- terms of existing power sales contracts (or of prospective contracts for projects not currently producing power), particularly as regards the ability to sell additional power (which provides as incentive to enhance the reservoir); and

- regulatory limitations for injecting into or producing from existing wells.

Some of these data may be publicly available, but it would be preferable in all cases to enlist the field operator to obtain the most complete information. This would build on the information presented below, giving DOE appropriate background material to assist in the decision-making process for EGS proposals. 


\subsubsection{Coso, California}

The Coso reservoir has temperatures of up to $650^{\circ} \mathrm{F}$. It occurs in granitic rock in extensional terrane at the western margin of the Basin and Range province. The field has $270 \mathrm{MW}$ of installed plant capacity and historically has maintained a high capacity factor. The field is currently operated by Caithness Corporation.

Two conditions make Coso a good candidate for EGS work: the existence of low-permeability wells in and around the field; and a degree of fluid depletion as a result of sustained production. Addressing these conditions has the potential to significantly improve the field's ability to sustain its current level of power output. The field operator already has had some success in thermally stimulating some Coso wells, and there have been preliminary discussions about stimulating a deep injection well (46A-19RD) in the BLM area (figure 2.2). As this reservoir is similar to other US high-temperature reservoirs with regions of low permeability, Coso would be an ideal place to evaluate the concept of extending or enhancing geothermal reservoirs.

Although Coso is located in an arid region, Caithness has indicated that separated brine could be used for EGS work. Also, shallow groundwater is potentially available from several sources. One such source is from wells located east of the field, near Coso Junction in Rose Valley. Caithness has been considering installation of a 10-mile pipeline to bring about 600 gallons per minute (gpm) of Rose Valley water into the field for injection. Another potential source is a shallow groundwater well in Section 4, northeast of the Navy I project area. This well was used to supply water for drilling operations early in the project. The capacity of the well is estimated at about $200 \mathrm{gpm}$, and Caithness is considering a pump test to better define this capacity. In addition, Caithness believes it would be possible to develop a supplemental source of injection 
TELEPHONE: $(510)$ 527-9876

FAX: (510) 527-8164

E-MAIL: MW@GEOTHERMEX.COM

water by drilling a shallow well on a former injection pad (13-16) within the Navy II project area. Thus, there appear to be several sources of water that could support EGS operations at Coso.

\subsubsection{East Mesa, California}

The East Mesa field produces from sedimentary formations (sandstones and siltstones) on the eastern margin of the Salton Trough. The field is operated by FPL Energy, Inc., and it has several binary power plants and a double flash plant, with a combined installed capacity of $105 \mathrm{MW}$.

Figure 2.3 shows the well locations.

All of the production wells are pumped, including those for the flash plant. Injection wells are located both in-field and on the periphery of the field, and reservoir cooling from injection breakthrough has occurred. The field has potential to benefit from EGS work to stimulate certain deep injection wells on the periphery of the field. These wells encountered high temperatures but relatively low permeability. Brine from the production separators could be used to stimulate these wells.

In addition, there may be potential to stimulate strata underlying the zones in which most production wells are completed. These underlying beds locally are productive in the vicinity of deep fractures. Such fractures were encountered by the discovery well (6-1), but this well has a small diameter and is not mechanically suitable for deepening or fracture stimulation. Other deep wells may be candidates for stimulation. 


\subsubsection{The Geysers, California}

Owing to its fluid deficiency, The Geysers is by definition an EGS. Since the early 1980s, when Unocal built pumping stations to withdraw water for injection from creeks and rivers, augmented injection has been used to maintain reservoir pressure and increase heat recovery. In September 1997, the Southeast Geysers Effluent Pipeline (SEGEP) began operating, providing about 5,400 gallons per minute of treated sewage effluent and Clear Lake water to the southeastern part of the field. This project has increased the injection fraction (the ratio of total injection to total production) in the southeastern part of the field from $25-30 \%$ to more than $60 \%$. Additional capacity is being considered for the SEGEP, and a second, similar project (the Santa Rosa pipeline) is underway.

The cost of building the SEGEP was approximately $\$ 32$ million, shared between industry, DOE, Lake County and the California Energy Commission. A gain in generation of about $40 \mathrm{MW}$ has already been observed. If one assumes a 10-year project life, the cost of the power produced from the SEGEP water is less than $\$ 0.01$ per $\mathrm{kW}$-hour, which is very attractive and shows the potential economic impact of EGS developments. While augmented injection at The Geysers is a remarkable EGS success story, we emphasize that it was not conceived of an as EGS project nor developed under the EGS program. There remains additional EGS work that could be undertaken at this field, including increasing augmented injection, and stimulating wells within and on the periphery of the field.

More augmented injection is clearly needed to enhance the heat recovery from The Geysers. This is particularly true for areas of the field that have little or no access to the water from the SEGEP or from pumping us surface waters, including the central and northern areas of the field (figure 2.4 ). The Santa Rosa effluent pipeline would have a capacity of 7,500 gallons per minute, and 
TELEPHONE: (510) 527-9876

FAX: (510) 527-8164

E-MAIL:MW@GEOTHERMEX.COM

the benefit would be spread over the central and northern areas of the field, which have been greatly depleted. Injection of this fluid would increase the injection fraction in these areas to more than $60 \%$. Additional proposals to maximize injection recovery in The Geysers are currently under consideration.

As shown in figure 2.4, it is difficult to get water for augmented injection from local sources or the effluent pipeline(s) to the northern and eastern parts of the field, including the Aidlin, CCPA, part of Units 11 and 17, Calistoga and Bear Canyon areas of the field. The following discussion relates to potential sources of water for augmented injection in those areas.

- Surface water use. This is allowed during the rainy season; the usable amount is often tied to stream gauge levels. At the Aidlin area, the California Department of Fish and Game places the burden on the operator to ensure that their withdrawal from Alder Creek during the rainy season does not lower the creek level to the point where the fish population would be affected. No withdrawal is permitted in the dry season.

- Groundwater withdrawals. To increase the injection fraction, the operator of the Aidlin project has drilled some relatively shallow groundwater wells, which produce from a few tens to perhaps 100 gallons per minute each. Property owners can drill and produce water wells, provided that the water is not produced from an aquifer that has other users. Apparently, the Franciscan Formation, which hosts both the groundwater and the steam reservoir, can be tapped for groundwater production at The Geysers without undue restriction. However, these wells also have a seasonal low in productivity; because of this, water storage may be the key to maintaining a constant level of augmented injection in some areas of the field. There is a water well in the CCPA area which was used to supply cooling water to the power plant when it operated, and it is likely that additional 
TELEPHONE: (510) 527-9876

FAX: (510) 527-8164

E-MAIL:MW@GEOTHERMEX.COM

groundwater sources could be developed in the area, and indeed in most areas of the field.

- Importation of effluent. Preliminary discussions have been held with the City of

Cloverdale to build a pipeline up to the Aidlin project, but no firm plans exist.

The Aidlin project has maintained an average injection fraction of up to $100 \%$, and the available injectors are sometimes used to maximum capacity. Therefore, another injection well may be needed at Aidlin to handle more augmented injection.

In the CCPA area, the power plant has been shut down for several years, and some of the wells are being abandoned. It may be possible for the adjacent operator (Calpine) to use some of the wells for production or injection if agreements with current owners and lessees in the CCPA area can be finalized. Some of the wells in the northwestern part of the field, including those in the CCPA, Unit 11 and Unit 17 areas (figure 2.4), are known to have corrosion problems associated with production of hydrogen chloride $(\mathrm{HCl})$. Some wells in these areas also have notably high gas content. Injection could be used not only to mine more heat but also to dilute the concentration of $\mathrm{HCl}$ and gases in the produced steam.

Numerous wells of opportunity are available for stimulation of permeability in The Geysers, both within the wellfield and in peripheral areas. If stimulation efforts are successful, the enhanced wells could be considered for either production or injection, depending on the injection strategy for the area in which they are located. Wells close to the Lake County or Santa Rosa pipelines could tap into these lines for injection water. Injection wells in more distant areas could draw on groundwater wells or surface run-off. For the latter, it is likely that a means of storing water would have to be developed to provide a continuous source of water during the dry season. 
TELEPHONE: (510) 527-9876

FAX: $(510)$ 527-8164

E-MAIL:MW@GEOTHERMEX.COM

\subsubsection{Heber, California}

Like East Mesa, the Heber field has both flash and binary plants. The field is operated by Ogden Geothermal Operations, Inc. Figure 2.5 shows a well location map. The flash plant is supplied by self-flowing wells on the eastern side of the field, drilled into the hottest portion of the developed reservoir. The production capacity of these relatively closely spaced wells is limited by pressure interference, so that not all of the existing wells can be used for production. A few have been converted to injection, but several are idle at present. It is unlikely that these idle wells would be good candidates for EGS stimulation work because of the close spacing of the wells and the fact that commercial permeability already exists. Moreover, many of the wells in this area of the field intersect unconsolidated sandstone units, which would not be suitable for hydraulic stimulation. Injection and production are already delicately balanced in this area to maintain pressure while minimizing cooling from injection breakthrough.

On the other hand, there is a relatively deep, tight well in the southern part of the field (GTW-6A) that could be the focus of stimulation work. This well is drilled into well-cemented sandstones that are more competent than the reservoir rocks further north, and therefore more suitable to hydraulic stimulation. Water from the Highline Canal, which runs along the southern side of the developed wellfield, could be purchased from the Imperial Irrigation District (IID) and used for stimulation. Ogden is presently focusing on decreasing the injection pumping requirements to maximize net output. If significant permeability could be developed in GTW-6A or other peripheral wells, it could be used for injection, which could have the dual benefit of sweeping more heat from the reservoir and potentially lowering injection pumping requirements. 


\subsubsection{Glass Mountain, California}

The geothermal resource at Glass Mountain has temperatures of up to $550^{\circ} \mathrm{F}$, hosted in young volcanic rocks at depths in the range of 2,000 to 9,000 feet. Several companies have held lease positions in the area at various times, and a number of temperature gradient holes and full-diameter deep wells have been drilled (figure 2.6). Calpine Corporation and California Energy General Corporation (CEGC) currently hold most of the leases in which drilling has occurred. Calpine has proposed a 49.9 MW project at Four Mile Hill, and CEGC has proposed a 48.8 MW project at Telephone Flat. Environmental Impact Statements for both projects are currently undergoing regulatory review. Transmission line routes for these projects are on the order of 20 miles long.

Four full-diameter deep wells have been drilled in the east-central part of the Known Geothermal Resource Area (KGRA). Three produced with potentially commercial outputs, while the fourth did not. Well test results to date suggest that Glass Mountain could benefit from EGS work to stimulate formation permeability. Several sources of water, including shallow water wells and brine from the geothermal reservoir, could be used to supply water for hydraulic fracturing operations. An EGS program to demonstrate effective stimulation methods in young volcanic rocks could have significant economic benefits, not just at Glass Mountain, but at a large number of geothermal fields in similar geologic settings worldwide.

\subsubsection{Salton Sea, California}

The Salton Sea field (figure 2.7) is one of the hottest in the world, with measured temperatures in excess of $700^{\circ} \mathrm{F}$. It occurs in sedimentary rocks (chiefly sandstones and siltstones) at depths ranging from 1,500 to 15,000 feet. The field is operated by CalEnergy Operating Corporation, a 
TELEPHONE: $(510) 527-9876$

FAX: (510) 527-8164

E-MAIL:MW@GEOTHERMEX.COM

subsidiary of MidAmerican Energy Holdings Company. Existing electrical generation plants have a capacity of $268 \mathrm{MW}$, and an additional $59 \mathrm{MW}$ of capacity is scheduled to go on line in 2000 .

A facility to recover approximately 34,000 metric tons per year of zinc from produced geothermal brine is under construction and is also scheduled to start operation in 2000. Permeabilities in the geothermal field are generally high, and the reservoir appears to receive sufficient pressure support from injection and natural recharge to assure stable long-term operations. However, there are areas with significantly lower permeability on the periphery of the region of active production and injection. A number of idle wells exist that could be stimulated as part of an EGS project.

The adjacent lake known as the Salton Sea is experiencing rising water levels and increasing salinity. Mitigation of these trends could be a significant collateral benefit of an EGS project. Governmental authorities at the local, state, and national levels are currently evaluating measures to lower both the water level and the salinity of the Salton Sea, including expensive proposals for long pipelines and desalination plants. An EGS program to stimulate permeability underground on the periphery of the Salton Sea geothermal field and to simultaneously dispose of significant volumes of Salton Sea water could attract funding from a variety of governmental and private sources.

One challenge to such a project would be to ensure that the injected Salton Sea water would be chemically compatible with brines in the geothermal reservoir. Mixing the water from the Sea with the brine in the geothermal reservoir would be expected to cause precipitation of minerals (such as anhydrite), which could reduce formation permeability. However, it may be possible to process Salton Sea water so as to yield two outflow streams: 1) a stream of water suitable for agricultural use; and 2) a stream of concentrated brine suitable for injection (including a chemical inhibitor to prevent precipitation). Another potential benefit of such a project would be to 
TELEPHONE: (510) 527-9876

FAX: (510) 527-8164

E-MAIL:MW@GEOTHERMEX.COM

provide an economical source of water for end users such as the CalEnergy zinc recovery process, which is currently projected to purchase water from the Imperial Irrigation District (IID) at an industrial rate.

\subsubsection{Puna, Hawaii}

The Puna geothermal reservoir has temperatures in excess of $685^{\circ} \mathrm{F}$ and presently supports a hybrid (flash-binary) power plant with an installed capacity of $30 \mathrm{MW}$. Zones of high productivity are closely associated with intrusions from the 1955 fissure eruption, which transects the Puna Geothermal Venture (PGV) project area from SW to NE (figure 2.8). Full-sized wells and slim holes have been drilled on the margins of the fissure eruptions, encountering lower temperatures and permeability than in the central zone. Separated production brine from the PGV project is injected into some of these peripheral wells. There is potential for an EGS program to increase the recovery of heat from the reservoir by stimulating low-permeability peripheral wells. This could play a significant role in sustaining the long-term output of the field. The PGV project currently has adequate injection capacity, but this could change if the production well which is currently being drilled yields fluid with a high liquid fraction. Thus, there is potential for a significant near-term economic advantage from an EGS program to develop additional injection capacity.

It should be noted that the PGV project operates under very tight regulatory requirements which might restrict the use of certain types of stimulation fluids (such as acid). Still, PGV believes it would be possible to obtain permits to allow hydraulic fracturing and the use of appropriate proppants. 


\subsubsection{Bradys Hot Springs, Nevada}

The Bradys Hot Springs field produces from wells on the northwest (down-thrown) side of a north-northeast-trending normal fault (the Bradys Fault). Production is primarily from permeable zones developed in Tertiary volcanics in the hanging wall of this fault (figure 2.9), and initial measured temperatures in this permeable zone were in the range of 340 to $360^{\circ} \mathrm{F}$. The depth of the producing zone ranges from about 1,000 to 6,000 feet, depending on the position of the well relative to the northwest-dipping fault surface. Wells on the southeast (foot wall) side of the fault have encountered temperatures of up to $409^{\circ} \mathrm{F}$ in metamorphic basement rocks, but the permeability of wells in the foot wall block has generally been low. A core hole $(\mathrm{BCH}-3)$ drilled in Section 12 in 1997 encountered temperatures of $405^{\circ} \mathrm{F}$ in a block that appears to have been relatively unaffected by past production; the formation permeability appeared to be low, but $\mathrm{BCH}$ 3 sustained artesian flow and has a positive shut-in wellhead pressure (32 pounds per square inch - gauge). The field has dual-flash power plant with a capacity of $26 \mathrm{MW}$ gross (21 MW net) (Schulman, 1995), and is currently operated by FPL Energy, Inc.

There is potential for an EGS stimulation program to develop permeability on the foot wall side of the Bradys Fault or in the block identified by BCH-3. Several wells completed in the footwall are currently open, and brine from the active production wells could be used for stimulation work. The current power output at Bradys is below the plant capacity due to gradual reservoir cooling, so an EGS program that could expand the volume of the productive reservoir and increase the temperature of produced fluids would have an immediate economic benefit. 


\subsubsection{Desert Peak, Nevada}

The Desert Peak field produces from metamorphosed sedimentary and igneous rocks of Mesozoic age at depths in the range of 3,000 to 7,000 feet (Faulder and Johnson, 1987). The reservoir rock has been extensively folded and faulted (Benoit, 1995). A 9 MW plant has been operating since December 1995, with production from two wells and injection into a third (figure 2.10). Several other wells exist which have encountered potentially commercial temperatures but low permeability. Measured reservoir temperatures are in the range of 400 to $425^{\circ} \mathrm{F}$. The field is currently operated by FPL Energy Inc., under a long-term lease from Mid-American Energy Holdings Company.

There is potential for EGS stimulation work in at least one existing well: a sidetrack of 22-22. The original well yielded 300,000 pounds per hour of flow on initial testing and had the highest recorded temperature in the field $\left(425^{\circ} \mathrm{F}\right.$ ) (Faulder and Johnson, 1987), but it was never connected to the power plant. Other wells may also be suitable for stimulation, depending on their current mechanical condition. With only a $9 \mathrm{MW}$ plant in operation, the reservoir has showed no significant pressure decline, so there is no current need for augmented injection. Under the current contractual arrangements for selling power from Desert Peak, there is little financial incentive for the operator to develop additional production capacity. Still, the field does present an opportunity to demonstrate EGS stimulation techniques in a moderate-temperature reservoir hosted in metamorphic rocks. A successful program could have significant long-term economic benefits at Desert Peak and at a number of other Basin and Range fields in similar geologic settings. 
TELEPHONE: (510) 527-9876

FAX: (510) 527-8164

E-MAIL:MW@GEOTHERMEX.COM

\subsubsection{Dixie Valley, Nevada}

Dixie Valley is a classic Basin and Range geothermal system, with a reservoir associated with a major range-bounding normal fault. The field has potential for two types of EGS work:

stimulation of low-permeability rock and injection augmentation to mitigate fluid deficiency.

Wells drilled to intercept the range-bounding fault zone at Dixie Valley have had a reasonable success rate, but a number of dry holes exist (Benoit, 1997). Permeability sometimes extends a short distance away from the fault zone in certain competent geologic units. A number of wells with temperatures high enough for power generation have been unsuccessful in penetrating zones of commercial permeability. These wells occur both between other successful wells and outside the area of known production. An EGS project here might be devised either to stimulate a dry hole which is believed to penetrate the fault zone, to increase the area of circulation in competent units adjacent to the fault zone, or to stimulate a high-temperature area beyond the region of known production. Considerable DOE-supported field work to characterize the stress field at Dixie Valley has already been performed (Hickman et al., 1998). One potential candidate for stimulation is well 82-5, which intercepts the fault zone and is located between other productive wells (figure 2.11). This type of stimulation work would be highly useful for characterizing the behavior of enhanced Basin and Range systems, and would set the stage for other, similar stimulation work in fault-controlled geothermal systems.

With production, the pressure in the Dixie Valley reservoir has declined, and Oxbow has initiated a program of augmented injection to maintain reservoir pressure. Some injection wells have been observed to return fluids to production wells more quickly than others, as documented by an extensive program of tracer testing (Rose et al., 1998). Oxbow is making an ongoing effort to configure its injection scheme so as to maximize heat recovery and minimize the potential for 
TELEPHONE: (510) 527-9876

FAX: (510) 527-8164

E-MAIL:MW@GEOTHERMEX.COM

injection breakthrough. An EGS program to further optimize injection augmentation at Dixie Valley could be of great value as a case study of how to effectively compensate for fluid deficiency in a Basin and Range system. Water for augmented injection at Dixie Valley has been produced from a shallow well (Goerenger) that yields warm groundwater $\left(80^{\circ} \mathrm{F}\right)$. Oxbow has recently installed a pump with a capacity of $2,000 \mathrm{gpm}$ on this well, and it reports that similar groundwater wells could be drilled in the area. Therefore, water availability appears not to be a limiting factor at Dixie Valley.

\subsubsection{Soda Lake, Nevada}

The Soda Lake field lies within the Carson Sink, a major basin in north-central Nevada.

Constellation Operating Services operates the field, which has binary generating units with a total capacity of approximately $24 \mathrm{MW}$ gross (19 MW net). The production wells in the field are all pumped. Productivity in the geothermal system is controlled by a combination of stratigraphic and structural features (McNitt, 1990). The fluid is derived from deep in the Carson Sink, and is inferred to flow up-dip in a coarse, pumice tuff unit at the base of the Truckee Formation into a structural and gravity high, where it is intercepted by the Soda Lake production wells. The static temperature in the production zone is approximately $356^{\circ} \mathrm{F}$, but temperatures in excess of $392^{\circ} \mathrm{F}$ have been measured in a well that penetrates the Mesozoic basement of granite, metavolcanic and metasedimentary rocks. Successful and unsuccessful wells are interspersed in the field (figure 2.12). The field currently is producing very steadily with a low rate of temperature decline, but the existing producers yield only enough fluid to run the plant at about $70 \%$ of its full capacity. The field has adequate injection capacity to run at full output if more produced brine were available. 
TELEPHONE: $(510)$ 527-9876

FAX: (510) 527-8164

E-MAIL:MW@GEOTHERMEX.COM

There is potential for EGS stimulation work at Soda Lake with two different objectives:

1) stimulation of the basement rock beneath the producing reservoir; or 2) stimulation of unsuccessful wells that penetrate the pumice tuff zone. In the past, acid stimulations have been tried without success. No stimulation has yet been attempted using hydraulic stimulation techniques. Injection water could be made available for such stimulation work. However, it is not clear that any of the non-productive wells that are still open would be suitable for stimulation, either because of small-diameter completions or the possibility of interference with existing producers. If a successful EGS stimulation program could be devised, it would have a direct economic benefit by allowing the plant's electrical output to be increased.

\subsubsection{Steamboat, Nevada}

There are two developments at Steamboat: the upper, high-temperature area, where Caithness Corporation owns and operates a $13 \mathrm{MW}$ flash plant; and the lower Steamboat area, where a 45-MW binary plant is installed (figure 2.13). Commercial permeability is found both in basement

(granitic and metamorphic rocks) and in Tertiary volcanic units. Upflow of high-temperature fluid occurs beneath the area developed for the flash plant, whereas the binary development taps the outflow zone (Mariner and Janik, 1995).

At Upper Steamboat, there is potential for EGS work both to stimulate permeability and to mitigate a fluid deficiency in the interpreted upflow area by improving the configuration of injection. Production is associated with a zone of naturally high permeability in basement rocks along a normal fault. Although most of the Caithness wells penetrate this structure, three wells (28-32, 13-5RD, and 32-5) were not commercially productive. These wells are located within a few hundred feet of active producers, and it may be possible to stimulate them for production to assist in maintaining output, with only modest pipeline modifications required to tie them into the 
TELEPHONE: $(510)$ 527-9876

FAX: (510) 527-8164

E-MAIL:MW@GEOTHERMEX.COM

gathering system. Alternatively, 32-5 could be stimulated to allow injection to improve pressure support near existing production wells. The source of this injection water could be separated brine, which is currently being injected at the Cox I-1 well more than half a mile to the northeast. No outside source of injection water for augmented injection is available at Upper Steamboat. The flash plant is currently operating about $4 \mathrm{MW}$ below capacity, so there is good potential for near-term economic advantage from EGS work to stimulate permeability and to improve the injection configuration.

At Lower Steamboat, there is potential for EGS work to enhance permeability in an idle injection well in the northwestern area of the lease supplying the binary plant. This well was drilled in the 1980 's and is completed in granodiorite. Enhancing the injectivity of this well would allow better distribution of injection and would alleviate cooling due to injection breakthrough. The production temperatures of existing producers could potentially be increased, and the net power output of the facility could be raised by shutting in one of the lower-temperature producers and saving the electricity needed to run its pump. The additional injection capacity could also forestall the installation of booster pumps that might otherwise be needed to accommodate increased brine flow at cooler temperatures. Further, having more injection capacity would enhance the attractiveness of installing additional production facilities, such as a planned facility utilizing Kalina cycle technology. Thus, there is significant potential for near-term economic advantage from an EGS program of permeability stimulation at Lower Steamboat.

\subsubsection{Stillwater, Nevada}

Like Soda Lake, the Stillwater field lies within the Carson Sink and is operated by Constellation Operating Services. Production is from a combination of artesian and pumped wells (figure 2.14), and the field has binary generating capacity totaling approximately $21 \mathrm{MW}$ gross (16 MW net). 
TELEPHONE: (510) 527-9876

FAX: (510) 527-8164

E-MAIL: MW@ GEOTHERMEX.COM

Recent electrical output has been about $70 \%$ of plant capacity. An EGS stimulation program to improve the permeability of injection wells has the potential for an immediate economic benefit by decreasing the parasitic load required to run injection pumps.

\subsubsection{Newberry, Oregon}

Two core holes and two deep full-diameter wells were drilled by CalEnergy Company, Inc. (CECI) in 1995 on the western flank of Newberry Crater (figure 2.15) (Spielman and Finger, 1998). The wells were completed in Tertiary volcanic rocks, and the deep wells penetrated several hundred feet of pre-Tertiary granitic basement below depths of about 8,700 feet. All had relatively low permeability ( $\sim 0.3$ millidarcy) and high temperatures (up to $600^{\circ} \mathrm{F}$ ). One of the deep wells (86-21) had mechanical damage and is scheduled to be plugged and abandoned later this year, together with one of the core holes (76-15). The remaining deep hole (23-22) is in excellent mechanical shape and would be an ideal candidate for EGS stimulation work. A shallow water well originally drilled to supply drilling water is still equipped with an electric submersible pump and could be used to supply water for hydraulic fracturing.

Newberry has no existing power plant, and the CECI wells are approximately 11 miles from the nearest transmission line access. Therefore, EGS work at Newberry is unlikely to have a direct economic benefit in the near term. However, as at Glass Mountain, demonstration of an effective stimulation technique at Newberry would provide useful information that might be applicable to a large number of geothermal resources hosted in young volcanic rocks worldwide, and could provide significant economic benefits in the long term. 
TELEPHONE: (510) 527-9876

FAX: (510) 527-8164

E-MAIL: MW@GEOTHERMEX.COM

\subsubsection{Cove Fort, Utah}

Cove Fort geothermal field is located in a transition zone between the Basin and Range and Colorado Plateau geologic provinces in southwestern Utah. The field is operated by the Utah Municipal Power Agency. Well locations are shown in figure 2.16. The field has near-term potential for an EGS program to mitigate a fluid deficiency that has caused pressure declines in a producing steam zone. Long-term potential also exists for stimulation of permeability in an underlying body of crystalline rock (quartz monzonite) that has been penetrated by one well.

The Bonnett Geothermal Plant at Cove Fort has an existing capacity of $11.5 \mathrm{MW}$, comprising 3 MW of binary units and an 8.5-MW steam flash unit. Production began in 1984. The plant is supplied by several wells producing from a steam zone in a Paleozoic sandstone and one pumped well producing from an underlying liquid-dominated zone in a Paleozoic carbonate unit (Huttrer, 1992). Pressures in the steam zone have declined with production. There is an idle well completed at the bottom of the steam zone. This presents the possibility of injecting brine from the liquid-dominated zone at a temperature and rate designed to extract additional heat and to supplement the recharge of mass to the steam zone. Such a program would need to be carefully designed to avoid condensation in the steam zone that could cause a further decline in pressures. The plant is currently operating at about $50 \%$ of capacity due to low steam-zone pressures. Thus, there is potential for a significant economic benefit if an appropriate program of injection augmentation can be implemented.

The well that produces from the liquid-dominated zone (P91-4) also penetrated a body of Tertiary quartz monzonite on bottom. The monzonite zone had higher temperatures $\left(326^{\circ} \mathrm{F}\right.$, versus an initial temperature of $316^{\circ} \mathrm{F}$ in the Paleozoic carbonate) but lower permeability. Geophysical evidence indicates that the monzonite is quite extensive and thus represents a significant 
opportunity for EGS development. However, P91-4 is not available for stimulation work because it is on production, and no other wells are completed in the monzonite. Therefore, no wells of opportunity currently exist for permeability enhancement at Cove Fort. In the longer term, if a successful program of stimulating permeability in the monzonite can be devised, this could have substantial economic benefits, because it would extend the applicability of EGS techniques to a wide range of resources with lower temperatures than have been worked with in the past.

\subsubsection{Roosevelt Hot Springs, Utah}

A $25 \mathrm{MW}$ flash plant (the Blundell Plant) has been operating at Roosevelt Hot Springs since 1984, supplied by wells drilled into fractured Tertiary volcanic and Precambrian metamorphic rocks on the east side of a major NNE-trending fault called the Opal Mound Fault (figure 2.17). To the west of the fault, temperatures are potentially commercial, but permeability is limited to the zone immediately adjacent to the fault. Utah State Geothermal Well 9-1, drilled about 1,600 feet west of the fault, encountered temperatures as high as $441^{\circ} \mathrm{F}$, but produced no significant quantities of geothermal fluids (Tripp et al., 1987). However, the well does show pressure communication with the producing wells east of the fault, and it is used to monitor pressures in the reservoir. An EGS program at Roosevelt could be proposed either to stimulate the productivity of 9-1 or to convert the well to injection to allow the heat west of the fault to be more effectively recovered. Water for this stimulation work could be supplied by separated brine, which is currently injected into wells more than a mile north of the producing wellfield.

At present, the Blundell Plant is operated by PacifiCorp, and the wellfield at Roosevelt Hot Springs is operated by Intermountain Geothermal Company (IGC), a subsidiary of MidAmerican Energy Holdings Company. Existing wells have been sufficient to allow IGC to maintain a surplus of steam above contractual requirements. Thus, there is no near-term economic incentive 
TELEPHONE: $(510) 527-9876$

FAX: (510) 527-8164

E-MAIL: MW@GEOTHERMEX.COM

for an EGS program to stimulate permeability at Roosevelt Hot Springs. However, if the output of the field is ever increased beyond the level provided for in the current IGC-PacifiCorp contract, an EGS program could provide significant economic benefits. 
TELEPHONE: $(510) 527-9876$

FAX: (510) 527-8164

E-MAIL:MW@GEOTHERMEX.COM

\section{POSSIBLE EGS DEMONSTRATION SCENARIOS}

\subsection{Background}

Milestone 5 of the EGS Strategic Plan states:

"By 2008, complete development and begin operating a cost-shared, comprehensive, pilotscale, demonstration project at an EGS site."

The reasoning for this approach is that, to achieve the EGS program's long-term goal of developing geothermal resources closer to the low-permeability, low-fluid content end of the spectrum, the risks and uncertainty of such developments need to be reduced. One or more demonstration projects would do just that.

EGS solicitations during the next few years will yield proposals for research and field projects that address particular barriers to EGS development (primarily the ability to manipulate and map permeability, and maximize heat recovery from the enhanced system). The purpose of undertaking this work is to reduce the risk and uncertainty associated with EGS development, thus setting the stage for moving forward from "research" projects to "development" projects, which require a significantly greater investment. We consider "development" to mean a project that demonstrates EGS-derived production of about $10 \mathrm{MW}$ (gross) or more; however, a demonstration project might be significantly smaller.

An EGS demonstration project could be one of the following: 
E-MAIL: MW@GEOTHERMEX.COM

- a project that supplies an existing geothermal power plant with additional generating capacity using EGS techniques;

- a separate generating facility adjacent to an existing geothermal development supplied by an EGS injection and production system; or

a stand-alone EGS demonstration plant in an area with no existing geothermal development.

We discuss each of these in the following sections.

\subsection{EGS Project Supplving Existing Geothermal Development}

The discussion of potential EGS development sites presented in Chapter 2 provides a starting point for demonstration projects of this type. Most of the sites with an existing infrastructure that could be used for the demonstration also have a need to increase or sustain output; to maintain the financial viability of some of these projects, it is critical to meet certain capacity requirements. The strategy for maintaining capacity in the past has often been make-up well drilling, but this often is often economic today given the price paid for electricity. In some reservoirs, make-up well drilling serves to exacerbate resource decline; thus, the decision of whether or not to drill is not always based on the economics of drilling, but on the nature of the problem at hand.

There are several well-known reservoirs that have experienced a significant production-induced pressure decline. In some cases, reservoir pressures have fallen to the point where production rates are pressure-limited. Considering the pressures that must be maintained further downstream of the well in the production system (i.e., in the gathering system, at the production header and 
ultimately at the turbine inlet), there is a minimum wellhead pressure that must be maintained. As reservoir pressure declines, the wellhead pressure is maintained by throttling the well; that is, by reducing the production rate. However, once the production rate becomes too low to be economic, the reservoir pressure limit is reached. Yet, in such fields, temperatures beyond the immediate vicinity of the wells often remain near their pre-exploitation value; therefore, most of the heat remains in the reservoir rock. By increasing the reservoir pressure by augmented injection, one can mitigate the decline in well productivity, and thereby help recover the residual heat energy.

The best-known example of this problem is The Geysers. Reservoir pressure was initially at about 500 psia and has now declined to about 150 psia across much of the field. Wellhead pressures cannot be allowed to fall much below about 100 psia, except in the areas where there have been significant modifications to the power plants. Other reservoirs where significant pressure declines have occurred include Coso and Dixie Valley, and perhaps others. In these fields, production has either already become limited by pressure decline, or may become pressure-limited in the future. An EGS development would be designed to replenish reservoir fluid by injection, thus supporting reservoir pressures and enabling more heat to be mined from the reservoir rock.

In other reservoirs, the intrinsically low permeability of the reservoir rock requires high injection pressures to dispose of the power plant wastewater, increasing the parasitic load (i.e., the amount of power consumed by the generating facility itself). In the worst cases, injection pressures may become high enough to require curtailment of production. While this situation could be mitigated by drilling more injection wells, in many reservoirs the siting of injection wells is a greater challenge than siting production wells, because the injectors must be close enough to producers to provide pressure maintenance yet far away enough to avoid premature cooling of production wells. In some reservoirs there is a serious shortage of injection sites where this balance between 


\section{GeothermEx, Inc.}

TELEPHONE: (510) 527-9876

FAX: (510) 527-8164

E-MAIL: MW@GEOTHERMEX.COM

pressure maintenance and cooling can be achieved. Hence, maximizing the injectivity at the few available injection sites becomes a priority.

Intrinsically low permeability of the reservoir rock also limits well productivity in some reservoirs.

Even if a reservoir is attractively hot and areally extensive, a minimum per-well productivity is required to make the project economic. Even within otherwise permeable reservoirs, tight zones are often present, particularly near the field margins. In such situations, the demonstration scenario would involve stimulating wells to improve production.

The use of EGS techniques to supply an existing facility would have the following advantages:

- It is a low-cost option that could use wells of opportunity to develop and demonstrate EGS techniques; no new power plant construction would be required.

- It would be popular with the US geothermal industry, because today's low power prices make mitigation of capacity decline uneconomic in many fields, and operators are seeking ways to maintain capacity at affordable cost.

- Depending on the fields chosen, a variety of conversion technologies (e.g., single- and dual-stage flash, water-cooled binary, air cooled binary and hybrid) could be supported, which would show a broad applicability of EGS techniques.

Development costs could span a wide range, and would be likely to include those associated with well re-completion, well stimulation, development of water sources for augmented injection (such as pipelines and groundwater wells) and increasing the pumping capacity to enable more water to be moved through the system. In a demonstration of augmented injection, the location and rate of 
injection would need to be carefully chosen to avoid premature breakthrough of injected water, and to enable the maximum possible benefit. The challenge of demonstrating permeability enhancement will be to design and conduct the most effective stimulation program. In any EGS development supplying an existing facility, the improvement associated with the EGS project would need to be quantified, and a way of disseminating information from the project to other interested parties would need to be devised.

\subsection{Separate EGS Facility Adjacent to Existing Geothermal Development}

In this scenario, a doublet, a triplet or even a "five-spot" well configuration (i.e., with one injector and one, two or four producers) would be drilled on the periphery of a hydrothermal system that has already been developed for geothermal power production. This would be the type of EGS requiring permeability enhancement. To be economic, the level of generation from each well group would need to be on the order of $2-6 \mathrm{MW}$ (essentially the same as that from a single hydrothermal production well). A modular power plant design that could be moved relatively easily from one demonstration site to another would be preferable, with back-pressure wellhead generators or binary generation, depending on resource conditions. It is highly likely that the existing transmission line would be used. It may be possible to use some existing wells for this type of project, although that should not be assumed. There could be significant savings in various infrastructure costs because of the proximity of the project to an existing geothermal development. Therefore, the main cost components would be the wells, the gathering system, the injection system and the power plant.

It is generally assumed that a hydrothermal project requires a capital cost of $\$ 2,000$ to $\$ 3,000$ per $\mathrm{kW}$ of installed capacity. About 30 to $40 \%$ of this capital cost is for field development, the remainder being for the gathering system, injection system and power plant. For an EGS project, 
the development costs associated with the gathering system, injection system and power plant should be very similar to a conventional hydrothermal development, but the field development costs will be higher. We have used the following method to estimate the field development costs for an EGS system based on the concept of permeability enhancement.

To date, EGS systems have used well doublets, and triplets have been considered. However, even the classic "five-spot" configuration used in the oil industry could be used to capture more of the injection water in the production wells. These configurations would need a total of 2 to 5 wells (one injector plus 1, 2 or 4 producers in each well group). In comparison, for a hydrothermal development, one injection well is typically required for every two production wells, although there are uncommon cases with a $1: 1$ injection to production well ratio, or even $1: 3$, or more. In the hydrothermal case, 1.5 wells (one producer and one-half of an injector) are needed to produce 2-6 MW. In an economic EGS system, the water injected in the injection well should be adequate to allow, from the associated 1 to 4 production wells, a total generation level similar to that expected in the typical hydrothermal well case. Therefore, instead of the 1.5 wells needed for hydrothermal projects, 2 to 5 wells are needed for an EGS project for equivalent generation capacity. This implies that the EGS well requirements would be 1.33 to 3.33 times that for hydrothermal projects for a similar level of generation. Furthermore, fracturing and fracture detection activities would increase the cost of EGS field development by about $30 \%$, yielding EGS field development costs ranging from 1.73 to 4.33 times that associates with hydrothermal development.

If $\mathrm{C}$ is the total development cost per $\mathrm{kW}$ for a hydrothermal project, and $\mathrm{F}$ is the fraction of the total development costs spend on field development, and the field development cost for an EGS project is $\mathrm{M}$ times the costs of an equivalent hydrothermal project, then the total cost of an EGS project $\left(\mathrm{C}_{\mathrm{EGS}}\right)$ can be written as: 
TELEPHONE: (510) 527-9876

FAX: (510) 527-8164

E-MAIL:MW@GEOTHERMEX.COM

$$
\mathrm{C}_{\mathrm{EGS}}=\mathrm{C}(\mathrm{F} \cdot \mathrm{M}-\mathrm{F}+1) \text {, }
$$

where $\mathrm{C}=\$ 2,000$ to $\$ 3,000$,

$\mathrm{F}=0.3$ to 0.4 , and

$\mathrm{M}=1.73$ to 4.33 .

Based on these considerations, Table 2 presents estimates of the plausible range of development costs for an EGS project involving enhancing a zone of intrinsically low permeability adjacent to a hydrothermal development. As the table shows, the total capital costs for such projects lie in the range of $\$ 2,500$ to $\$ 7,000$ per $\mathrm{kW}$ of installed capacity. The above considerations show that the total development cost of an EGS project using a doublet should lie within the range of costs for a typical hydrothermal project, whereas if a five-spot configuration is needed, the costs could be nearly three times that for a hydrothermal project.

Unfortunately, the operations and maintenance (O\&M) costs for such as project cannot be determined at this time because of the uncertainty associated with the estimation of make-up well requirements. To date, neither field experimentation nor computer simulation has clearly demonstrated a reliable basis for either forecasting the cooling of the produced fluid with time or estimating the associated make-up well drilling costs, which are likely to be the largest component of the O\&M costs.

The main advantage of this type of development over that discussed in section 3.2 is that it demonstrates feasibility of a stand-alone development, but does not have the burden of the costs of transmission line access or development of other infrastructure from scratch. An added consideration in this scenario is that it will be necessary to demonstrate that the project has no detrimental effect on the existing development. 
TELEPHONE: (510) 527-9876

FAX: (510) 527-8164

E-MAIL:MW@GEOTHERMEX.COM

\subsection{Stand-Alone (Greenfield) EGS Project}

This would obviously be the most costly of the three options, as it is likely that transmission line access would be required and some initial exploration efforts to define the thermal anomaly (unless some gradient holes or exploration wells already exist). As in the previous scenario, it is difficult to determine how much production capacity would be available from a doublet, triplet or five-spot, but 2 - $6 \mathrm{MW}$ per well group is a reasonable assumption for an economic project. The development cost for such a project should in the range of $\$ 2,500$ to $\$ 7,000$ per $\mathrm{kW}$ of installed capacity, as estimated above, plus the capital costs associated with transmission line access, which is likely to be needed, and items of general infrastructure. As mentioned above, the O\&M costs of such a project cannot yet be estimated.

The highest-risk option usually has the highest potential benefit, and such is the case here, particularly if a development were located outside the western part of the country. However, even in areas where the heat flow is high, there remain significant challenges to be overcome in developing such a system. As yet, it is unknown if permeability can be sufficiently enhanced to develop an economic level of production per well group; this will be the focus of U.S. field experimentation efforts in the near future. 


\section{REFERENCES}

Benoit, D., 1995. Forced folding and Basin and Range Geothermal Systems. Transactions, Geothermal Resources Council, Vol. 19, pp. 155-163.

Benoit, D., 1997. Dixie Valley Research Introductory Comments and Overview. Proceedings, $21^{\text {st }}$ Workshop on Geothermal Reservoir Engineering, Stanford University, January 1997, pp. $121-122$.

Faulder, D.D., and S.D. Johnson, 1987. Desert Peak geothermal field performance. Transactions, Geothermal Resources Council, Vol. 11, pp. 527-533.

Hickman, S., J. Sass, C. Williams, R. Morin, C. Barton, M. Zoback and D. Benoit, 1998. Fracture permeability and in situ stress in the Dixie Valley, Nevada, geothermal reservoir. Federal Geothermal Research Program Update, Fiscal Year 1997, March 1998, pp. 4 -189 to 4 -196.

Huttrer, G.W., 1992. Geothermal exploration at Cove Fort - Sulphurdale, Utah, 1972 - 1992. Transactions, Geothermal Resources Council, Vol. 16, pp. 89 - 95.

Mariner, R.H., and C.J. Janik, 1995. Geochemical data and general model for the Steamboat Hills geothermal system, Wahoe County, Nevada. Transactions, Geothermal Resources Council, Vol. 19 , pp. $191-200$.

McNitt, J.R., 1990. Stratigraphic and structural controls of the occurrence of thermal fluid at the Soda Lakes geothermal field, Nevada. Transactions, Geothermal Resources Council, Vol. 14, pp. 1,507 - 1,512. 
TELEPHONE: (510) 527.9876

FAX: (510) 527-8164

E-MAIL: MWOGEOTHERMEX.COM

Rose, P.E., W.R. Benoit, and M.C. Adams, 1998. Tracer testing at Dixie Valley, Nevada, using pyrene tetrasulfonate, amino G, and fluorescein. Transactions, Geothermal Resources Council, Vol. 22, pp. 583-587.

Sass, J.H., and A. Robertson-Tait, 1998. Potential for "Enhanced Geothermal Systems" in the western United States. Proceedings of the 4th International HDR Forum, Strasbourg, France, September 28 - 30, 1998.

Schulman, G., 1995. Low temperature flashed steam power generation. Proceedings of the World Geothermal Congress, 1995, Florence, Italy, pp. 2059-2061.

Spielman, P.B., and J.T. Finger, 1998. Well test results of exploration drilling at Newberry Crater, Oregon in 1995. Proceedings, 23rd Workshop on Geothermal Reservoir Engineering, Stanford University, January 1998.

Tripp, A.C., H.P. Ross, J. A. Stodt, and P.M. Wright, 1987. Surface-to borehole electromagnetic experiment at Roosevelt Hot Springs: a feasibility study. Transactions, Geothermal Resources Council, Vol. 13, pp. 289-293. 


\section{GeothermEX, InC. $\begin{array}{r}\text { 5221 CENTAAL AVENUE, SUITE 201 } \\ \text { RICHMOND, CALIFOANIA 94804-5829 }\end{array}$}

TELEPHONE: (510) 527-9876

FAX: $(510) 527-8164$.

E-MAIL: GEOTHERMEX COMPUSERVE.COM

TABLES 
Table 1. Prioritized List of Potential Sites for Enhanced Geothermal Systems (EGS)

\begin{tabular}{|c|c|c|c|c|c|c|c|c|c|c|c|c|}
\hline Field & $\begin{array}{l}\text { Existing } \\
\text { Power } \\
\text { Plant }\end{array}$ & \begin{tabular}{|c|} 
Availability of \\
Transmission \\
Capacity \\
\end{tabular} & $\begin{array}{c}\text { Prospects } \\
\text { for } \\
\text { Economic } \\
\text { Advantage }\end{array}$ & $\begin{array}{l}\text { Areas of } \\
\text { Low } \\
\text { Permeability }\end{array}$ & \begin{tabular}{|c|} 
Availability of \\
Wells for \\
Stimulation \\
Work \\
\end{tabular} & $\begin{array}{c}\text { Availability of } \\
\text { Water for } \\
\text { Stimulation } \\
\text { Work }\end{array}$ & $\begin{array}{l}\text { Evidence } \\
\text { of } \\
\text { Fluid } \\
\text { Deficiency }\end{array}$ & $\begin{array}{l}\text { Availability of } \\
\text { Wells for } \\
\text { Augmented } \\
\text { Injection }\end{array}$ & $\begin{array}{c}\text { Availability of } \\
\text { Water for } \\
\text { Augmented } \\
\text { Injection }\end{array}$ & \begin{tabular}{|c|} 
Extensional \\
Stress \\
Regime
\end{tabular} & $\begin{array}{l}\text { Ranking } \\
(10= \\
\text { Highest) }\end{array}$ & Comments \\
\hline Coso & $x$ & $x$ & $x$ & $x$ & $x$ & $x$ & $x$ & $x$ & $x$ & $x$ & 10 & $\begin{array}{l}\text { Making up fluid deficiency has significant } \\
\text { potential to help sustain output. Some } \\
\text { water available for injection augmentation. } \\
\text { Existing deep well is candidate for } \\
\text { iniection stimulation. }\end{array}$ \\
\hline The Geysers & $x$ & $x$ & $x$ & $x$ & $x$ & $x$ & $x$ & $x$ & $x$ & $x$ & 10 & $\begin{array}{l}\text { Concept of mitigating fluid deficiency has } \\
\text { already demonstrated. Limited water } \\
\text { available for additional injection. Could } \\
\text { lower NCG and H2S levels. }\end{array}$ \\
\hline Cove Fort & $x$ & $x$ & $x$ & $x$ & & $x$ & $x$ & $x$ & $x$ & $x$ & 9 & $\begin{array}{l}\text { Pressures in steam zone have declined. } \\
\text { Existing well completed near bottom of } \\
\text { steam zone could allow injection of } \\
\text { separated brine to mitigate fluid deficiency. } \\
\text { Plant currently at } 50 \% \text { capacity. Project } \\
\text { is at lower end of temperature spectrum } \\
\text { (produced brine at } 305^{\circ} \mathrm{F} \text { ). }\end{array}$ \\
\hline Dixie Valley & $x$ & $x$ & & $x$ & $x$ & $x$ & $x$ & $x$ & $x$ & $x$ & 9 & $\begin{array}{l}\text { Plant running at capacity, so EGS would not } \\
\text { have immediate economic benefit. Would } \\
\text { help sustain output in long run. Injection } \\
\text { augmentation already under way. EGS } \\
\text { potential in stimulating tight wells. }\end{array}$ \\
\hline Salton Sea & $x$ & $x$ & $\mathrm{x}$ & $x$ & $x$ & $x$ & & $x$ & $x$ & $x$ & 9 & $\begin{array}{l}\text { Potential benefit to operator in developing } \\
\text { lower-cost water supply for zinc recovery. } \\
\text { Large potential societal benefit in lowering } \\
\text { and desalinizing Salton Sea. Field is not } \\
\text { considered fluid-deficient, but water from } \\
\text { Salton Sea could be injected if chemical } \\
\text { incompatibility can be solved. }\end{array}$ \\
\hline $\begin{array}{l}\text { Upper } \\
\text { Steamboat }\end{array}$ & $x$ & $x$ & $x$ & $x$ & $x$ & $x$ & $x$ & $x$ & & $x$ & 9 & $\begin{array}{l}\text { Plant currently at about } 63 \% \text { of capacity. } \\
\text { Potential for increase of } 4-5 \mathrm{MW} \text { by } \\
\text { stimulating tight well for injection and } \\
\text { by improving pressure support. } \\
\text { Reservoir temperatures relatively low } \\
\text { (mid-300s }{ }^{\circ} \mathrm{F} \text { ). }\end{array}$ \\
\hline $\begin{array}{l}\text { Bradys Hot } \\
\text { Springs }\end{array}$ & $x$ & $x$ & $x$ & $x$ & $x$ & $x$ & & & & $x$ & 7 & $\begin{array}{l}\text { Tight wells southeast of field (in footwall } \\
\text { of interpreted fault) could potentially be } \\
\text { stimulated to production. Plant currently } \\
\text { operating below capacity. }\end{array}$ \\
\hline
\end{tabular}


Table 1. Prioritized List of Potential Sites for Enhanced Geothermal Systems (EGS)

\begin{tabular}{|c|c|c|c|c|c|c|c|c|c|c|c|c|}
\hline Field & $\begin{array}{l}\text { Existing } \\
\text { Power } \\
\text { Plant }\end{array}$ & $\begin{array}{c}\text { Availability of } \\
\text { Transmission } \\
\text { Capacity }\end{array}$ & $\mid$\begin{tabular}{c|} 
Prospects \\
for \\
Economic \\
Advantage
\end{tabular} & $\begin{array}{l}\text { Areas of } \\
\text { Low } \\
\text { Permeability }\end{array}$ & $\begin{array}{l}\text { Availability of } \\
\text { Wells for } \\
\text { Stimulation } \\
\text { Work }\end{array}$ & $\begin{array}{c}\text { Availability of } \\
\text { Water for } \\
\text { Stimulation } \\
\text { Work }\end{array}$ & \begin{tabular}{|c} 
Evidence \\
of \\
Fluid \\
Deficiency
\end{tabular} & \begin{tabular}{|c|} 
Availability of \\
Wells for \\
Augmented \\
Injection
\end{tabular} & $\begin{array}{l}\text { Availability of } \\
\text { Water for } \\
\text { Augmented } \\
\text { Injection }\end{array}$ & \begin{tabular}{|c|} 
Extensional \\
Stress \\
Regime
\end{tabular} & $\begin{array}{c}\text { Ranking } \\
(10= \\
\text { Highest })\end{array}$ & Comments \\
\hline East Mesa & $x$ & $x$ & $x$ & 20 & $x$ & $x$ & & & & $x$ & 7 & $\begin{array}{l}\text { Stimulation potential in injection wells with } \\
\text { limited permeability. Also, there is potential } \\
\text { to stimulate production wells to establish } \\
\text { better connection with deep productive } \\
\text { fractures. }\end{array}$ \\
\hline Heber & $x$ & $x$ & $x$ & $x$ & $x$ & $x$ & & & & $x$ & 7 & $\begin{array}{l}\text { Stimulation existing injection wells could } \\
\text { reduce parasitic load and increase net } \\
\text { power output. }\end{array}$ \\
\hline $\begin{array}{l}\text { Lower } \\
\text { Steamboat }\end{array}$ & $x$ & $x$ & $x$ & $x$ & $x$ & $x$ & & & & $x$ & 7 & $\begin{array}{l}\text { Stimulation of existing well northwest of } \\
\text { field could allow relocation of injection } \\
\text { and mitigation of cooling. This could allow } \\
\text { shutting in coolest producer and } \\
\text { decreasing parasitic load. }\end{array}$ \\
\hline Stillwater & $x$ & $x$ & $x$ & $x$ & $x$ & $x$ & & & & $x$ & 7 & $\begin{array}{l}\text { Injection wells on periphery of field have } \\
\text { low permeability and high wellhead } \\
\text { pressures. Stimulation of these wells } \\
\text { could decrease parasitic load and increase } \\
\text { net power output. }\end{array}$ \\
\hline Desert Peak & $x$ & $x$ & & $x$ & $x$ & $x$ & & & & $x$ & 6 & $\begin{array}{l}\text { Existing tight well could be stimulated with } \\
\text { separated brine from current production } \\
\text { wells. Current energy sales contract is } \\
\text { under litigation, so economic advantage } \\
\text { is unclear. }\end{array}$ \\
\hline Puna & $x$ & $x$ & & $x$ & $x$ & $x$ & & & & $x$ & 6 & $\begin{array}{l}\text { Existing injection capacity is adequate } \\
\text { but could be injection-limited depending on } \\
\text { result of currently drilling well. EGS } \\
\text { potential in stimulating tight injectors. }\end{array}$ \\
\hline $\begin{array}{l}\text { Roosevelt } \\
\text { Hot Springs }\end{array}$ & $x$ & $x$ & & $x$ & $x$ & $x$ & & & & $x$ & 6 & $\begin{array}{l}\text { Existing tight well could potentially be } \\
\text { stimulated to production. Current } \\
\text { contract limits economic incentive for } \\
\text { field operator. }\end{array}$ \\
\hline Soda Lake & $x$ & $x$ & $x$ & $x$ & & $x$ & & & & $x$ & 6 & $\begin{array}{l}\text { Temperatures above } 390^{\circ} \mathrm{F} \text { in Mesozoic } \\
\text { basement. No existing well suitable for } \\
\text { stimulation. Plant currently at about } \\
70 \% \text { of capacity. }\end{array}$ \\
\hline
\end{tabular}


Table 1. Prioritized List of Potential Sites for Enhanced Geothermal Systems (EGS)

\begin{tabular}{|c|c|c|c|c|c|c|c|c|c|c|c|c|}
\hline Field & $\begin{array}{l}\text { Existing } \\
\text { Power } \\
\text { Plant }\end{array}$ & $\begin{array}{c}\text { Availability of } \\
\text { Transmission } \\
\text { Capacity }\end{array}$ & \begin{tabular}{|c|} 
Prospects \\
for \\
Economic \\
Advantage
\end{tabular} & $\begin{array}{l}\text { Areas of } \\
\text { Low } \\
\text { Permeability }\end{array}$ & \begin{tabular}{|c|} 
Availability of \\
Wells for \\
Stimulation \\
Work
\end{tabular} & \begin{tabular}{|c|} 
Availability of \\
Water for \\
Stimulation \\
Work
\end{tabular} & \begin{tabular}{|c|} 
Evidence \\
of \\
Fluid \\
Deficiency
\end{tabular} & \begin{tabular}{|c|} 
Availability of \\
Wells for \\
Augmented \\
Injection
\end{tabular} & \begin{tabular}{|c|} 
Availability of \\
Water for \\
Augmented \\
Injection
\end{tabular} & $\begin{array}{c}\text { Extensional } \\
\text { Stress } \\
\text { Regime }\end{array}$ & $\begin{array}{c}\text { Ranking } \\
(10= \\
\text { Highest })\end{array}$ & Comments \\
\hline $\begin{array}{l}\text { Glass } \\
\text { Mountain }\end{array}$ & & & & $x$ & $x$ & $x$ & & & & & 3 & $\begin{array}{l}\text { Reservoir temperatures up to } 550^{\circ} \mathrm{F} . \\
\text { Existing full-diameter wells available. } \\
\text { Well test results suggest potential } \\
\text { benefit from stimulation. Water } \\
\text { supply wells available. }\end{array}$ \\
\hline Newberry & & & & $x$ & $x$ & $x$ & & & & & 3 & $\begin{array}{l}\text { Existing full-sized well has high temperature (over } \\
580^{\circ} \mathrm{F} \text { ) but low permeability. Existing water supply } \\
\text { well could allow stimulation work. Another full- } \\
\text { sized well was drilled but is damaged. }\end{array}$ \\
\hline
\end{tabular}


TELEPHONE: (510) 527-9876

FAX: (510) 527-8164

E-MAIL:MW@GEOTHERMEX.COM

Table 2: Estimate of Capital Costs for an EGS Project Involving Permeability Enhancement

Hydrothermal Project Development Cost

(\$/kW installed)
Fraction of Cost Devoted to Field Development in Hydrothermal Fields
Multiplier for EGS

Development
EGS Project Development Cost ( $\$ / k W$ installed)

$\begin{array}{llll}2,000 & 30 \% & 1.73 & 2,437 \\ 2,000 & 30 \% & 4.33 & 2,997 \\ 2,000 & 40 \% & 1.73 & 2,583 \\ 2,000 & 40 \% & 4.33 & 4,663 \\ 3,000 & 30 \% & 1.73 & 3,656 \\ 3,000 & 30 \% & 4.33 & 5,996 \\ 3,000 & 40 \% & 1.73 & 3,875 \\ 3,000 & 40 \% & 4.33 & 6,995\end{array}$


TELEPHONE: (510) 527-9876

FAX: (510) 527-8164

E-MAIL: GEOTHERMEX COMPUSERVE.COM

\section{FIGURES}




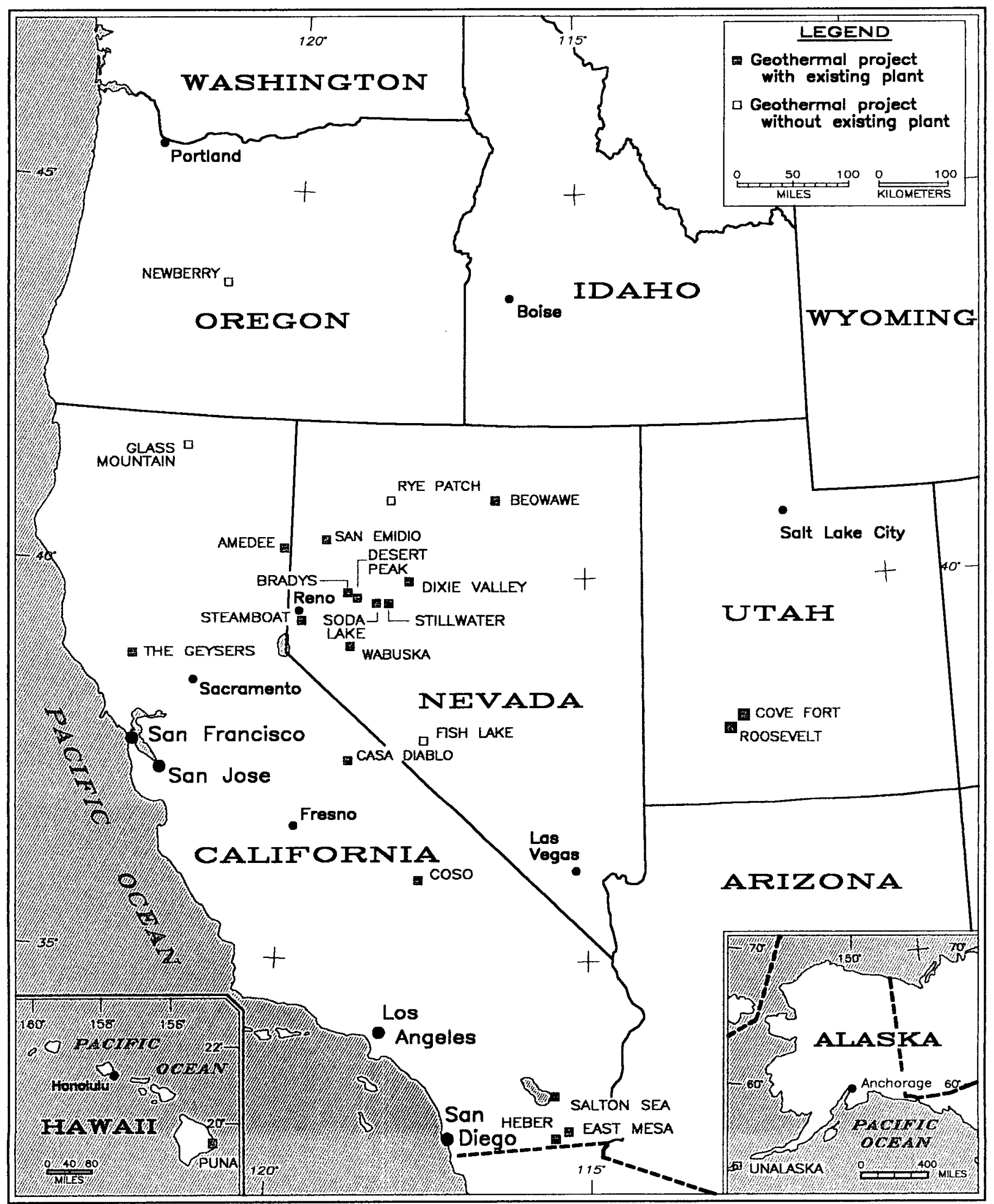

Figure 2.1: Location of geothermal projects in the western United States 1999, GeothermEx, Inc. EGSWUS/120CT99/P2446/EMY1/190/4M/E_F1.SSS 


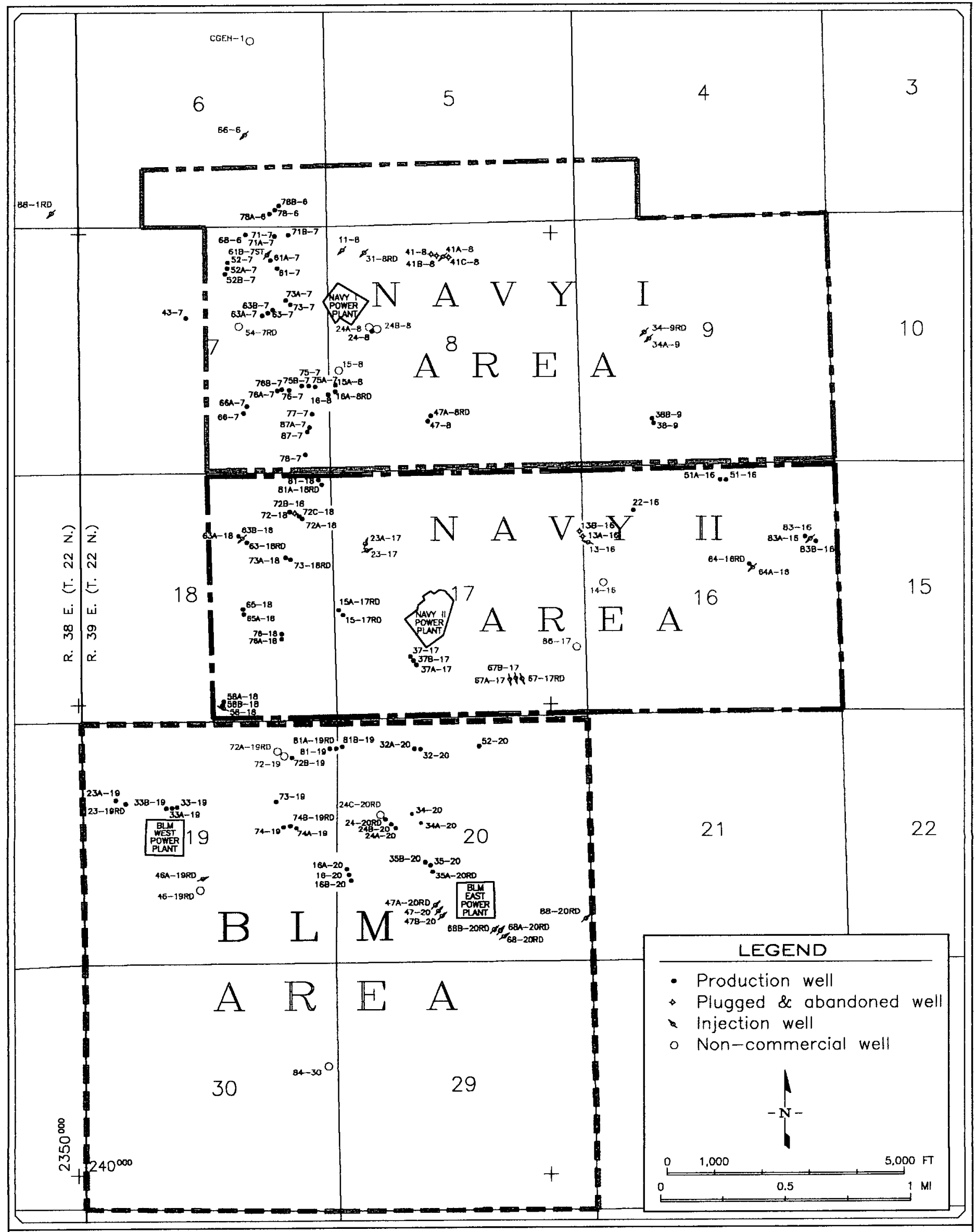

Figure 2.2: Well location map, Coso geothermal field, California 


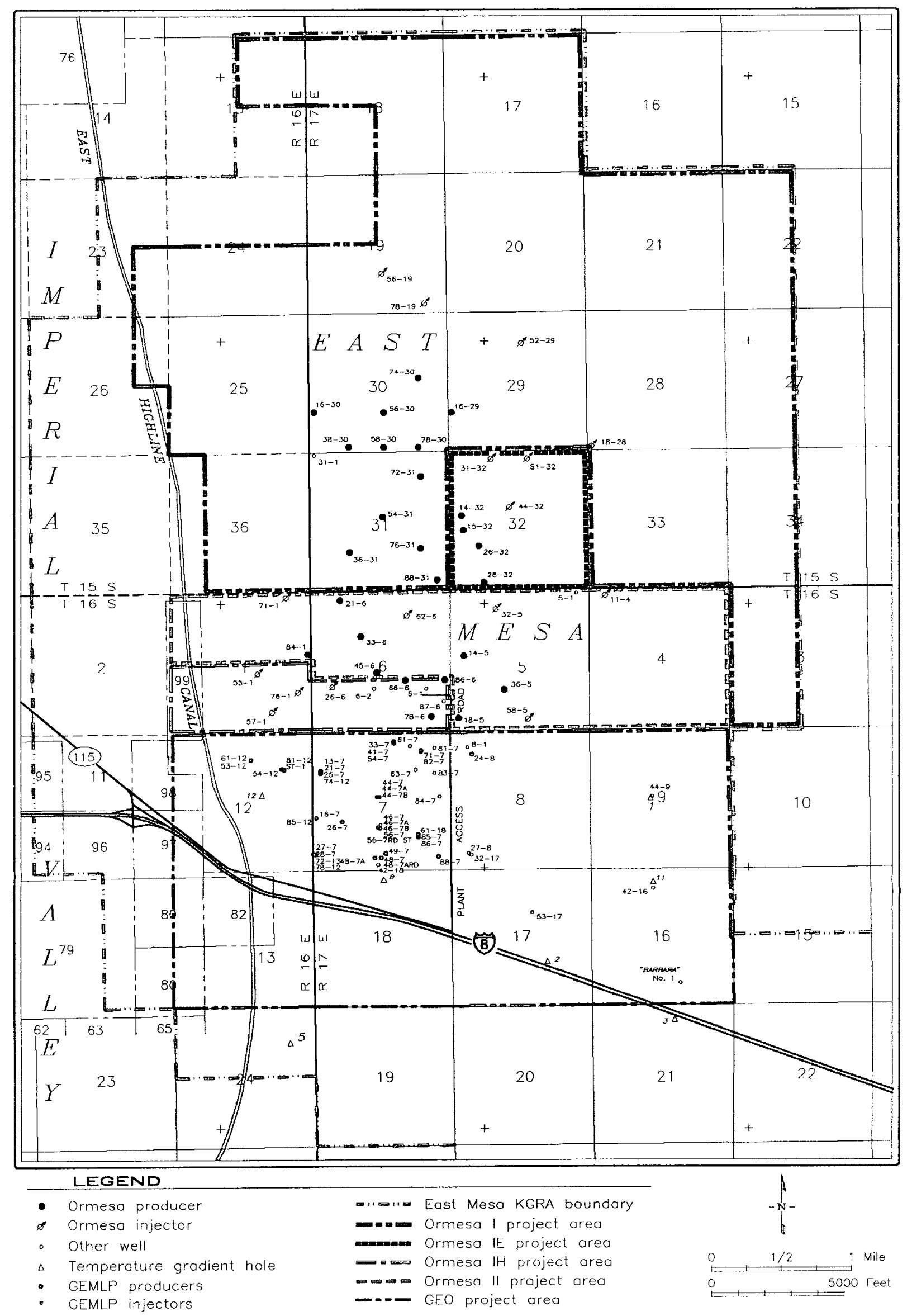

Figure 2.3: Well location map, East Mesa geothermal field, California 


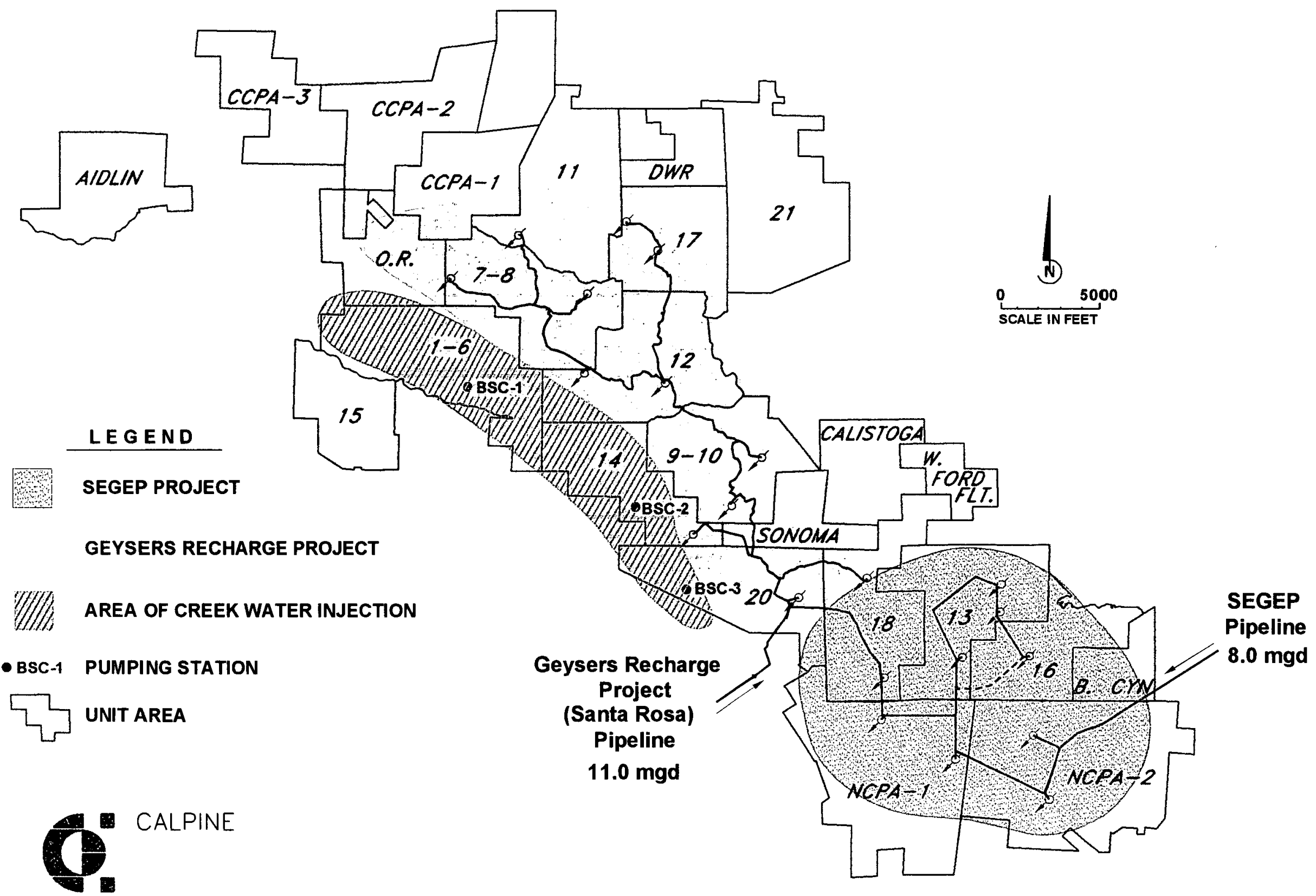

Figure 2.4: Power plant areas and augmented injection projects at The Geysers geothermal field, California

EGSGEYS/120CT99/P2446 after TB0101.DWG 


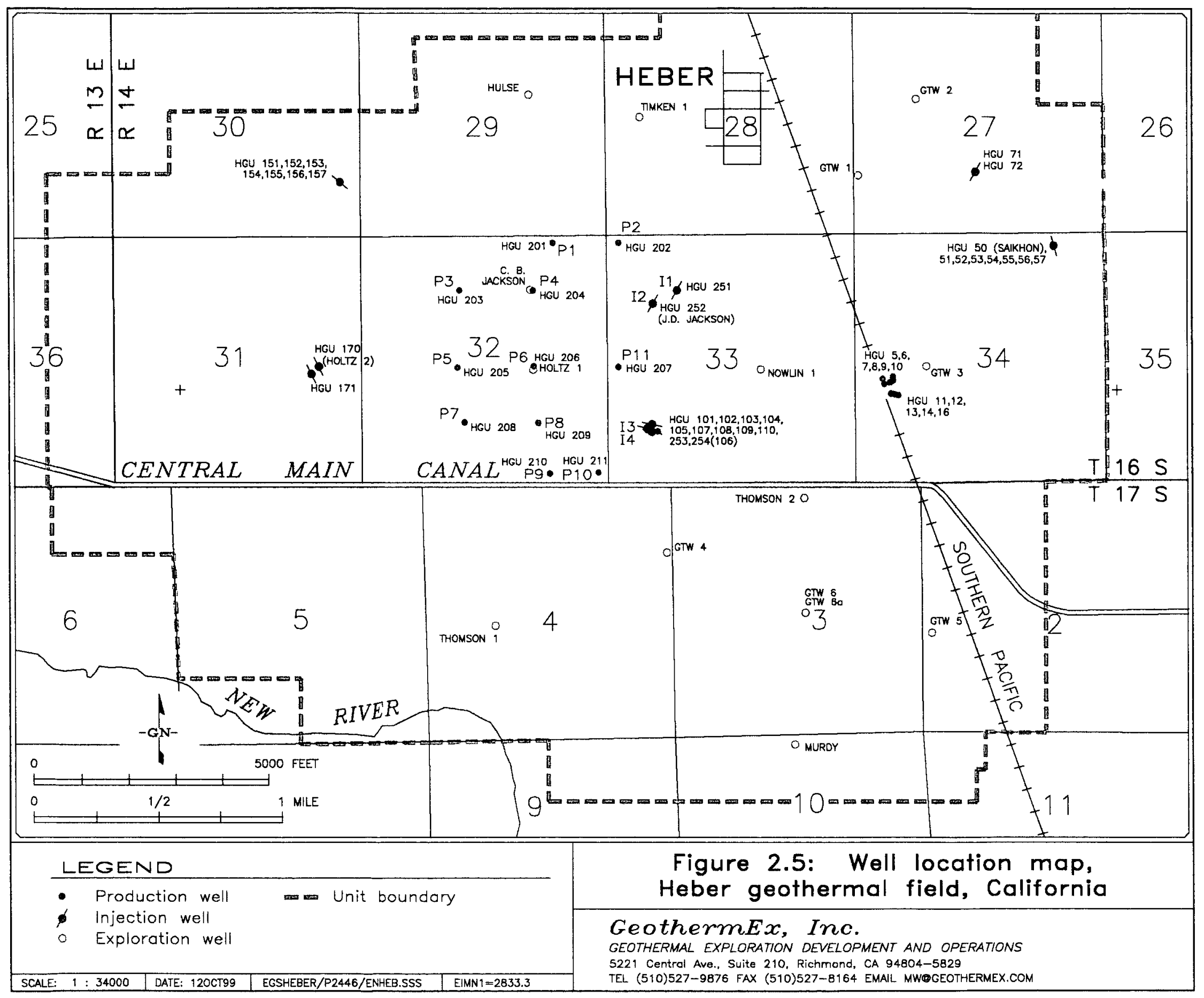




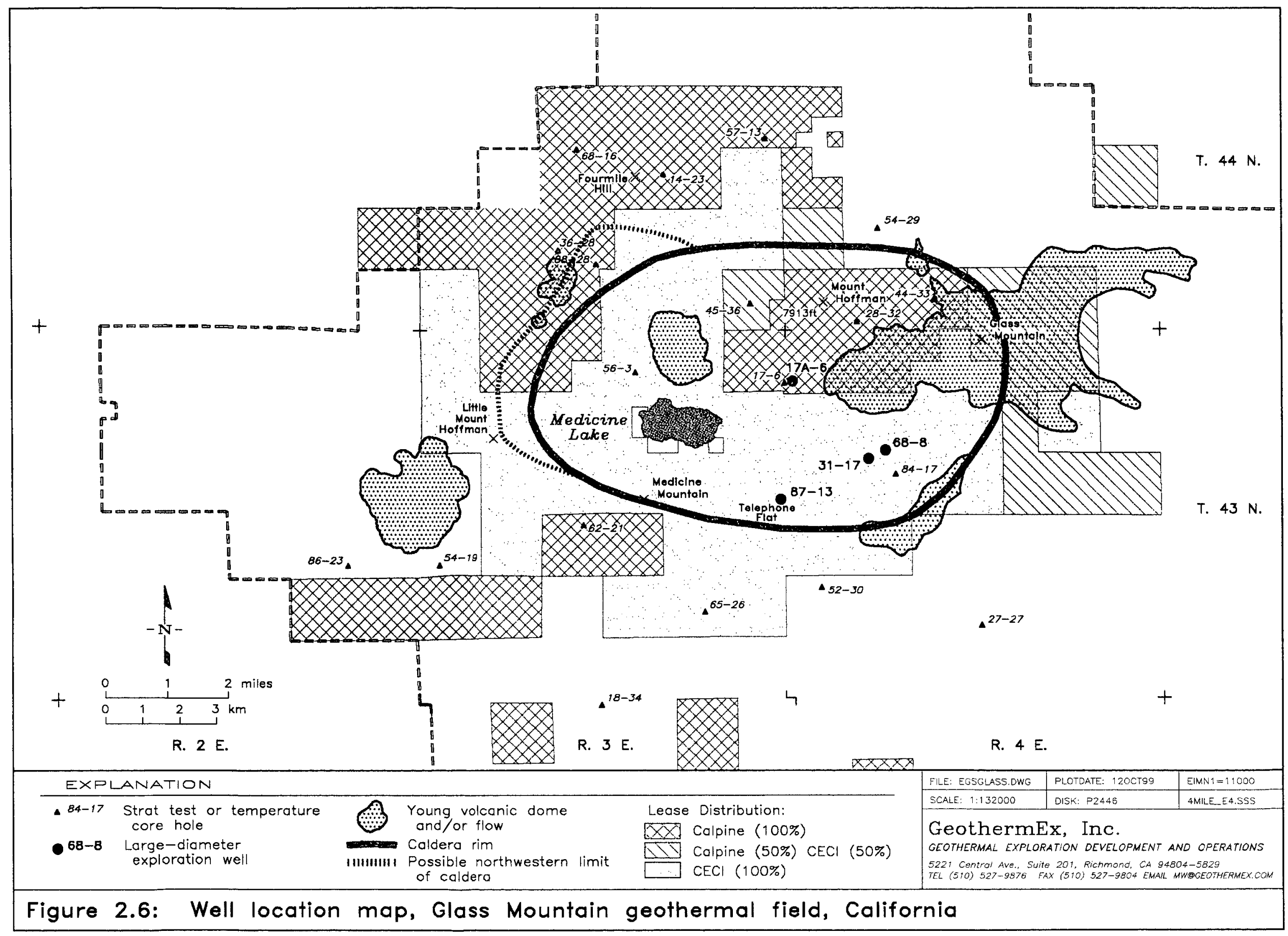




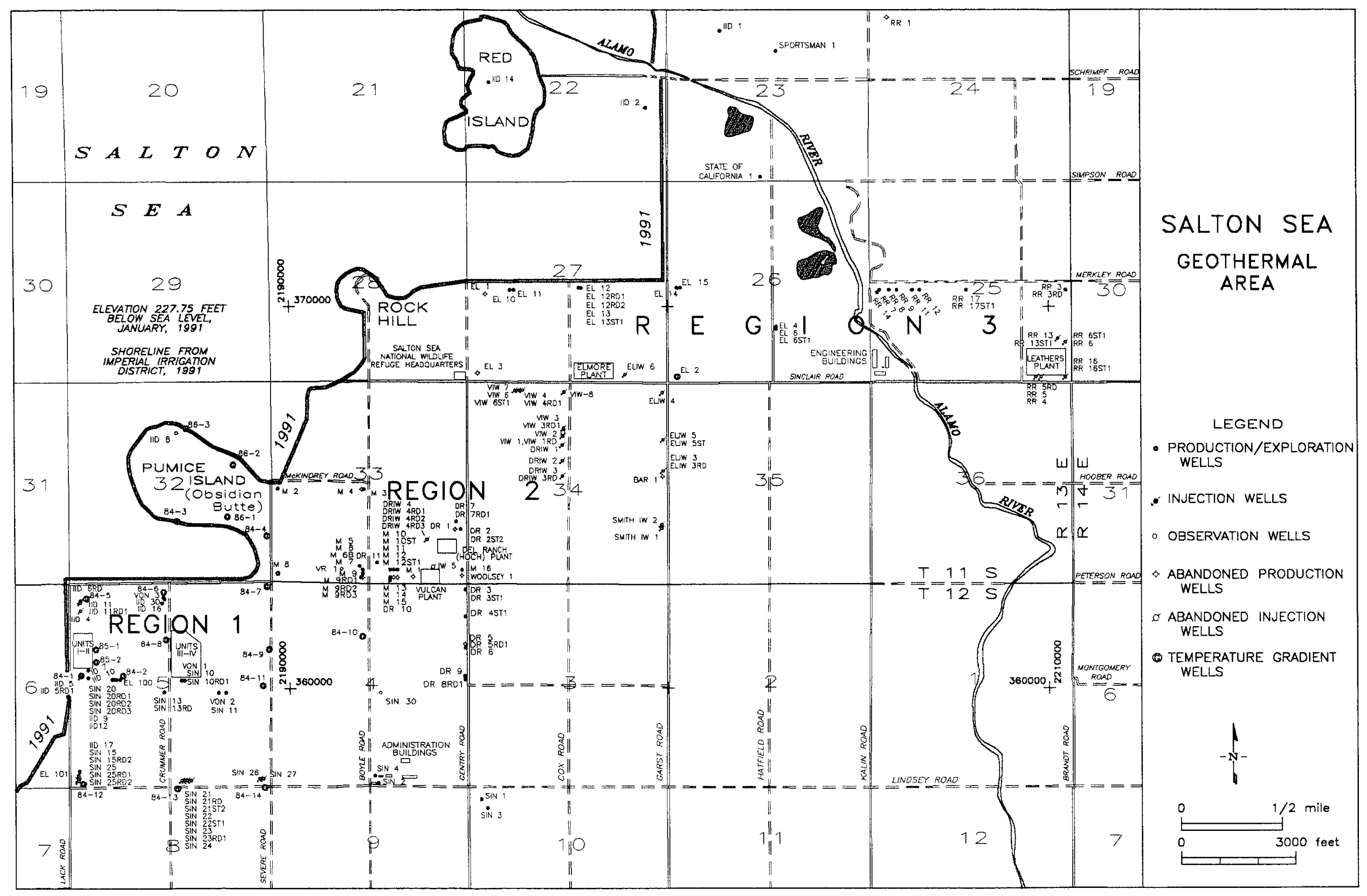

Figure 2.7: Well location map, Salton Sea geothermal field, California 


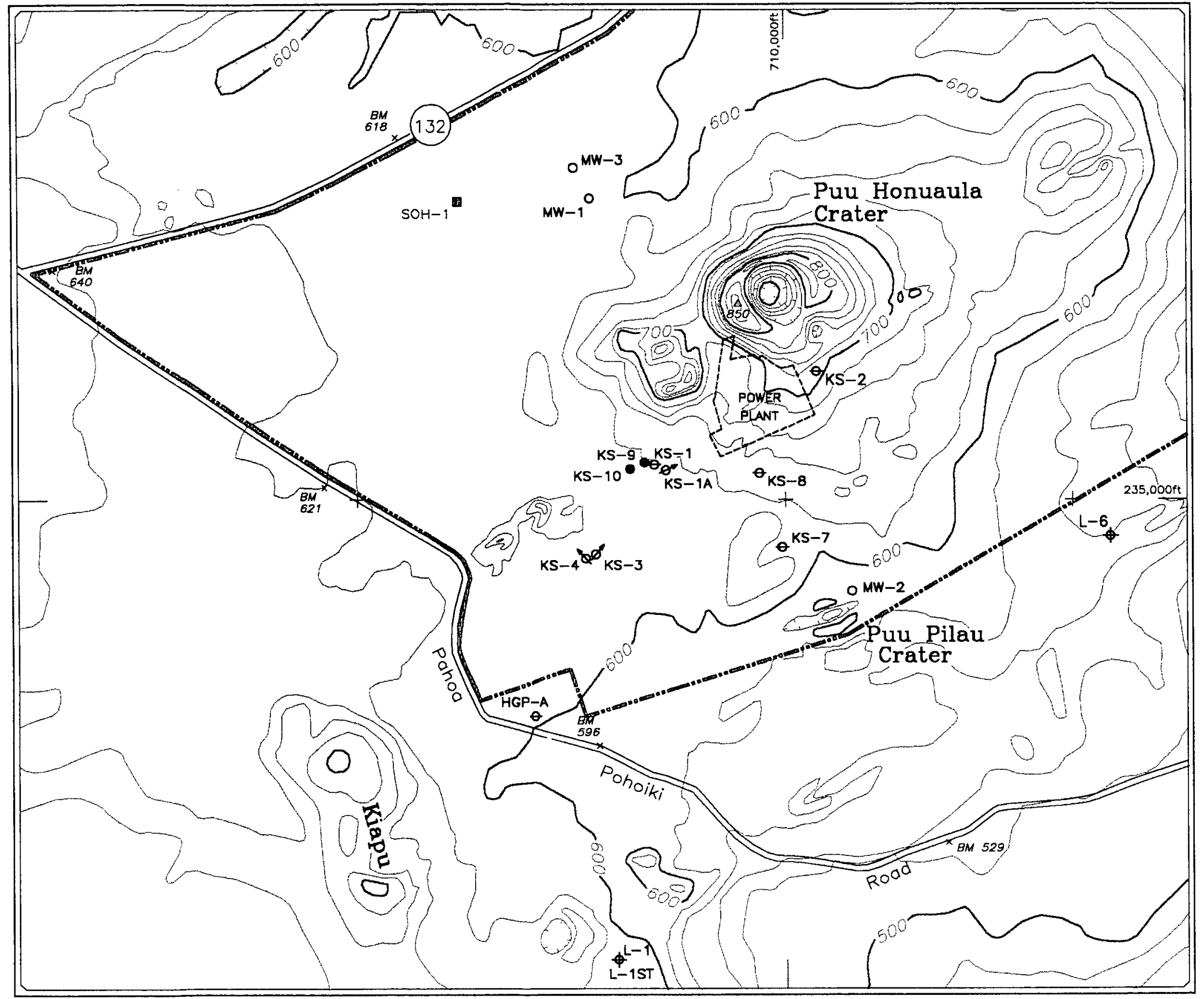

LEGEND

- Lease boundary -600- Elevotion contour. feet (msl),
interval 20 feet

- Scientific observation hole ( $\mathrm{SOH}$ ) Deep geothermal wells:

- Production well

$\varnothing$ Injection well

\& Dry hole

* Plugged hole

- Monitor hole

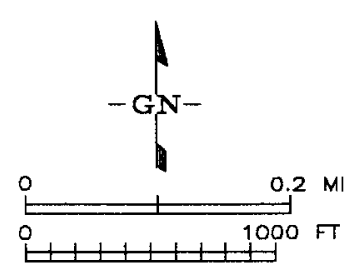

Figure 2.8: Well location map, Puna geothermal field, Hawaii 


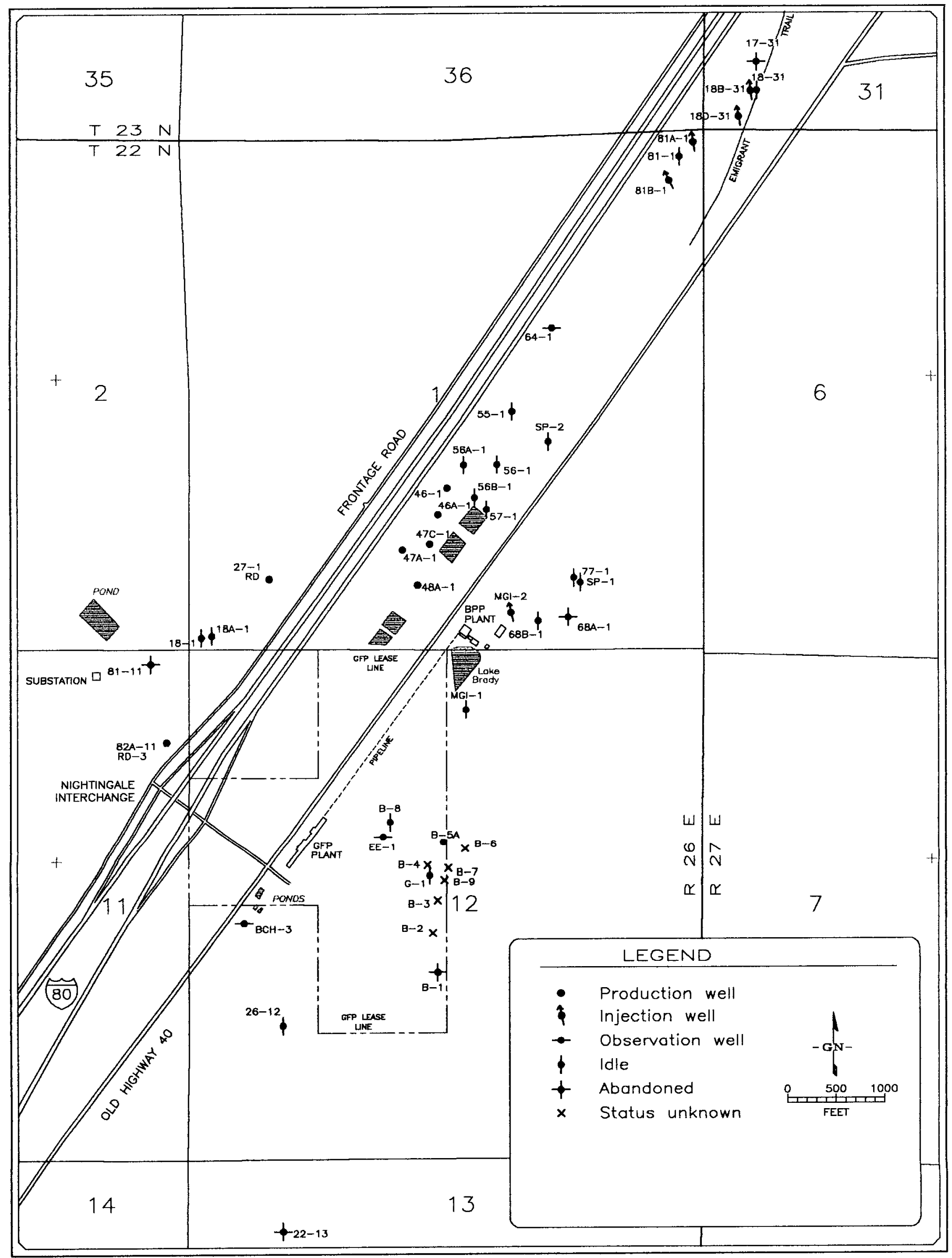

Figure 2.9: Well location map, Bradys Hot Springs geothermal field, Nevada 


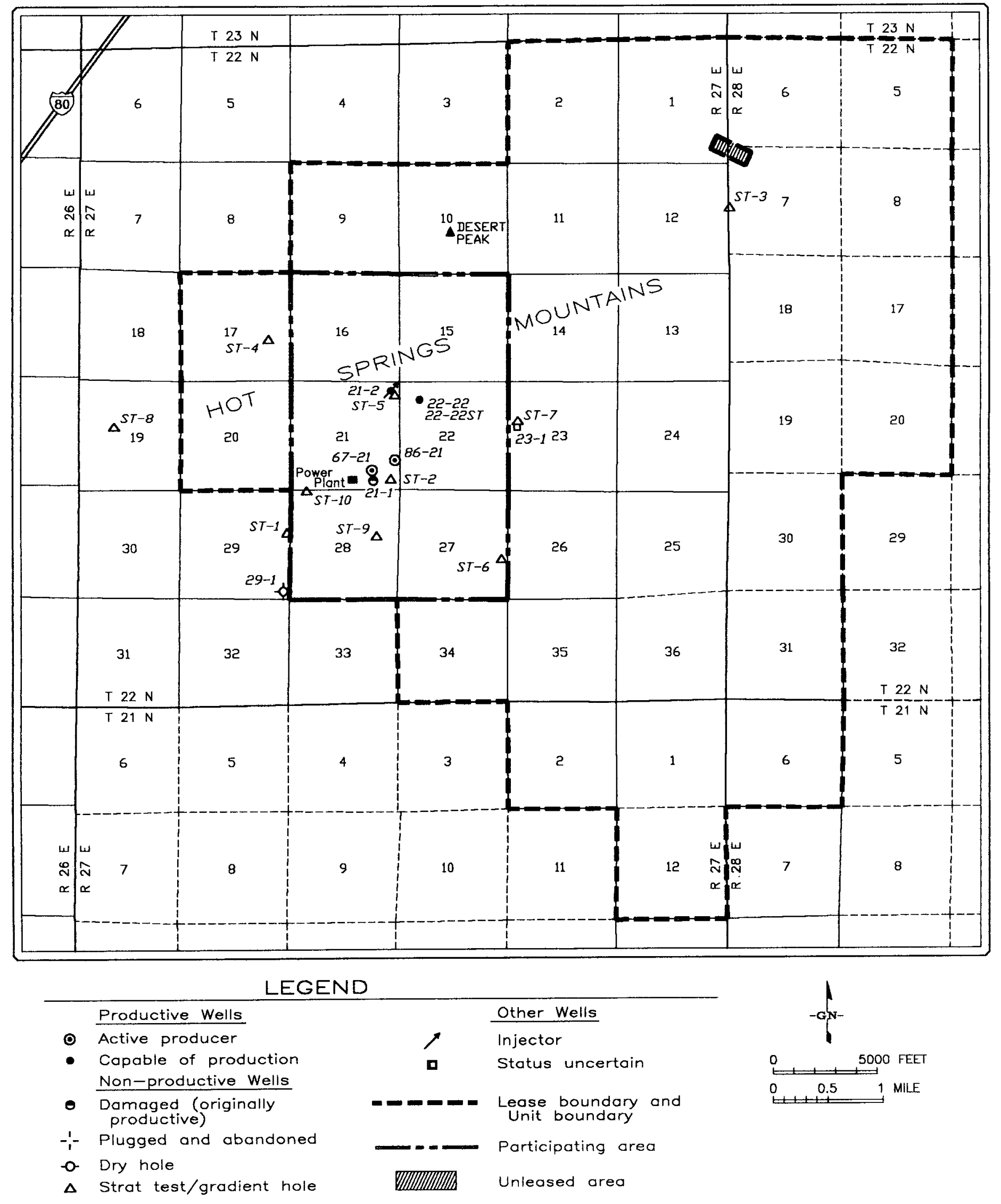

Figure 2.10: Well location map, Desert Peak geothermal field, Nevada 1999, GeothermEx, Inc. EGSDESER/1200T99//22446/EMWY1=6400/EGSDEER.SSS 


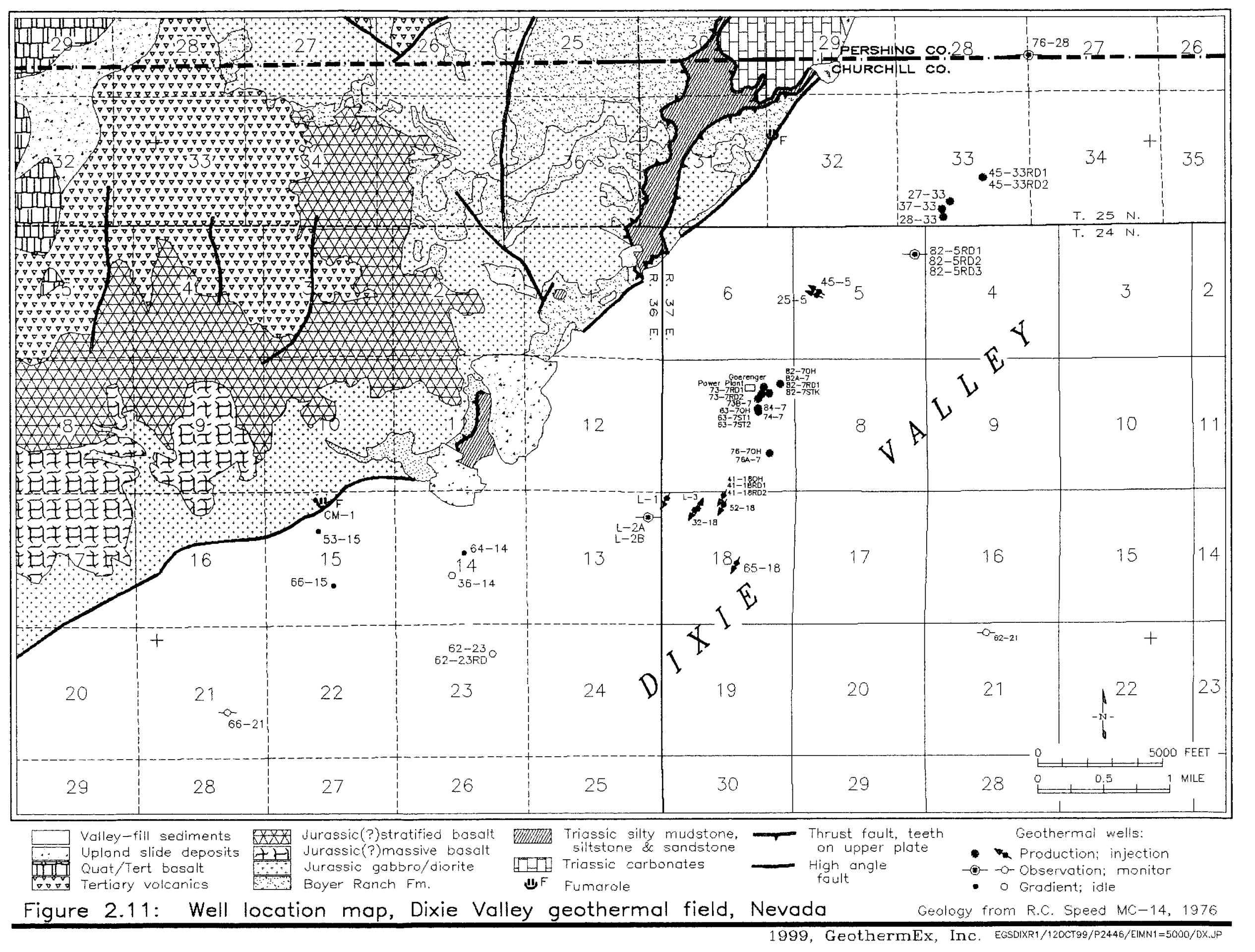




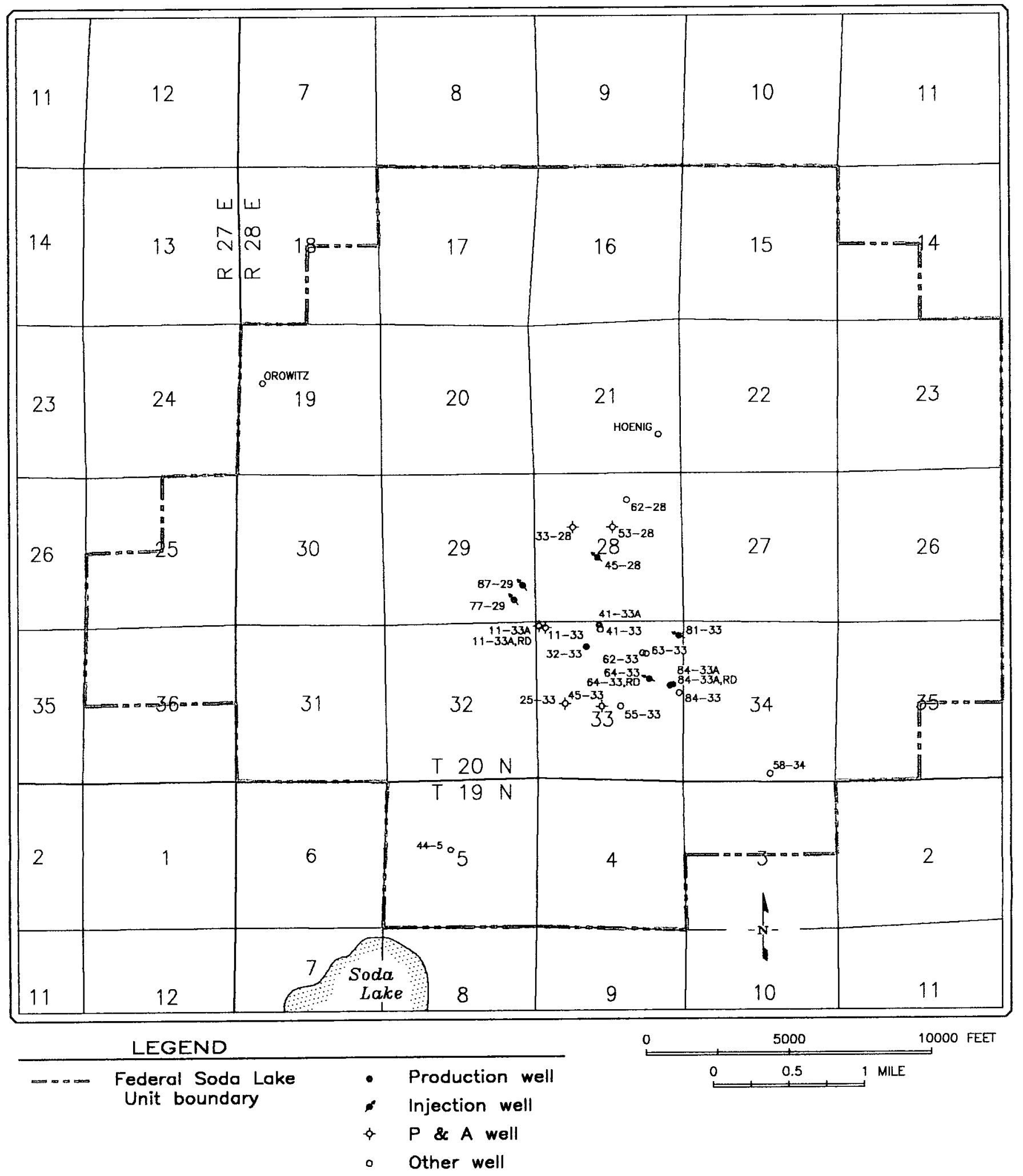

Figure 2.12: Well location map, Soda Lake geothermal field, Nevada 1999, GeothermEx, Inc. EGSSODA/130CT99/P2446/EIMY1=5000/EGSSODA.SSS 


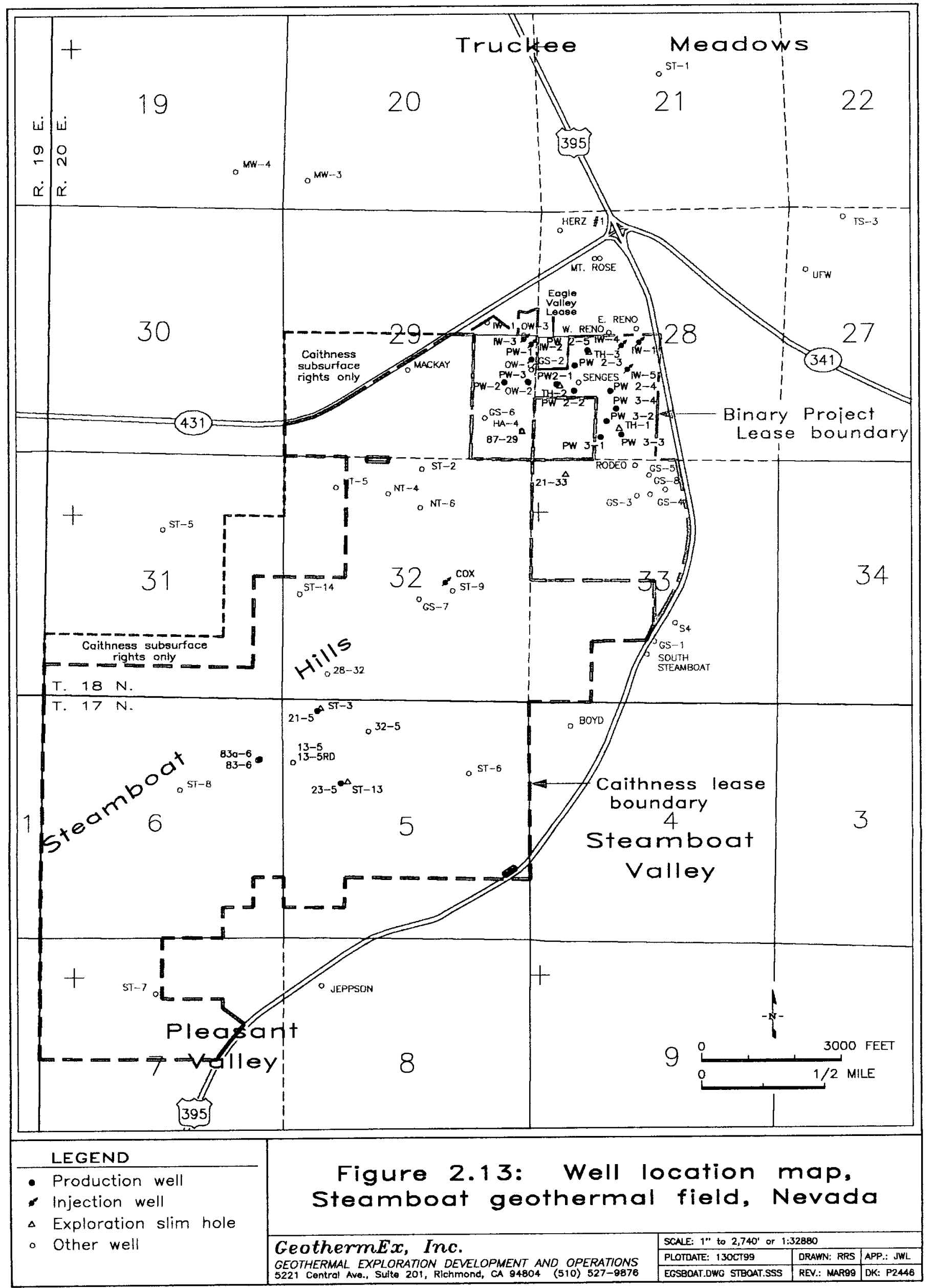




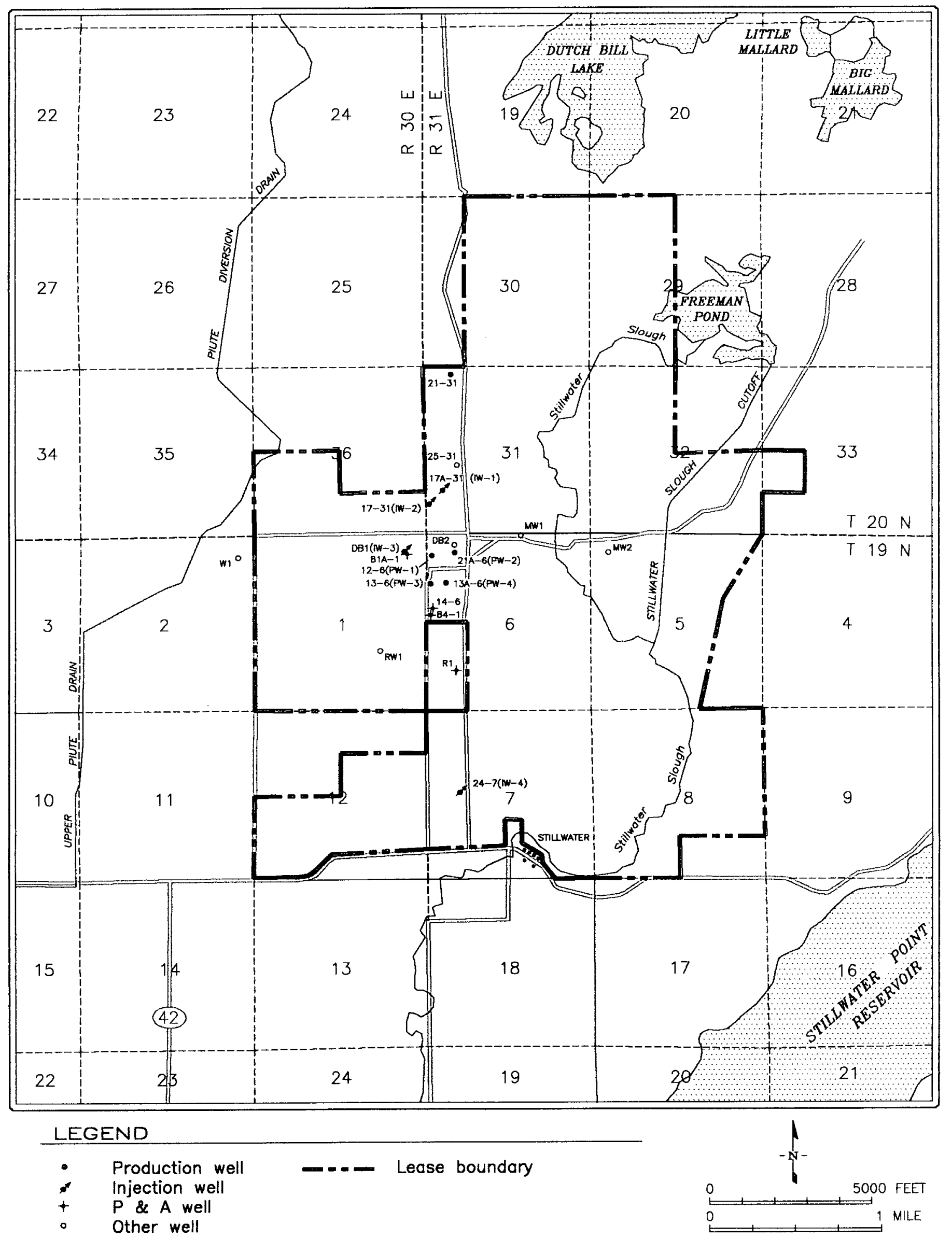

Figure 2.14: Well location map, Stillwater geothermal field, Nevada 


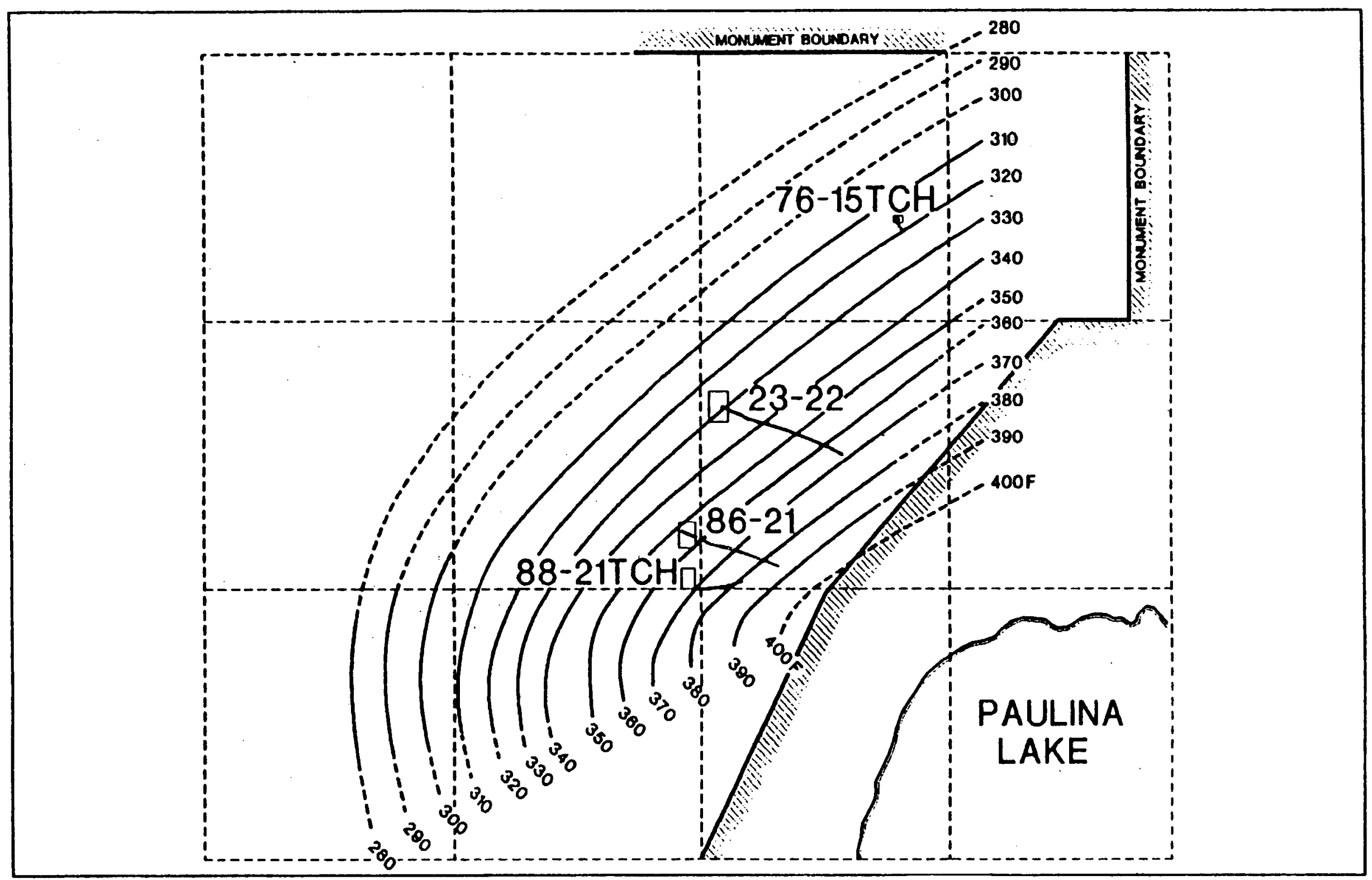

Temperature isotherms at 2,000 feet above sea level

Figure 2.15: Well location map, Newberry geothermal field, Oregon 


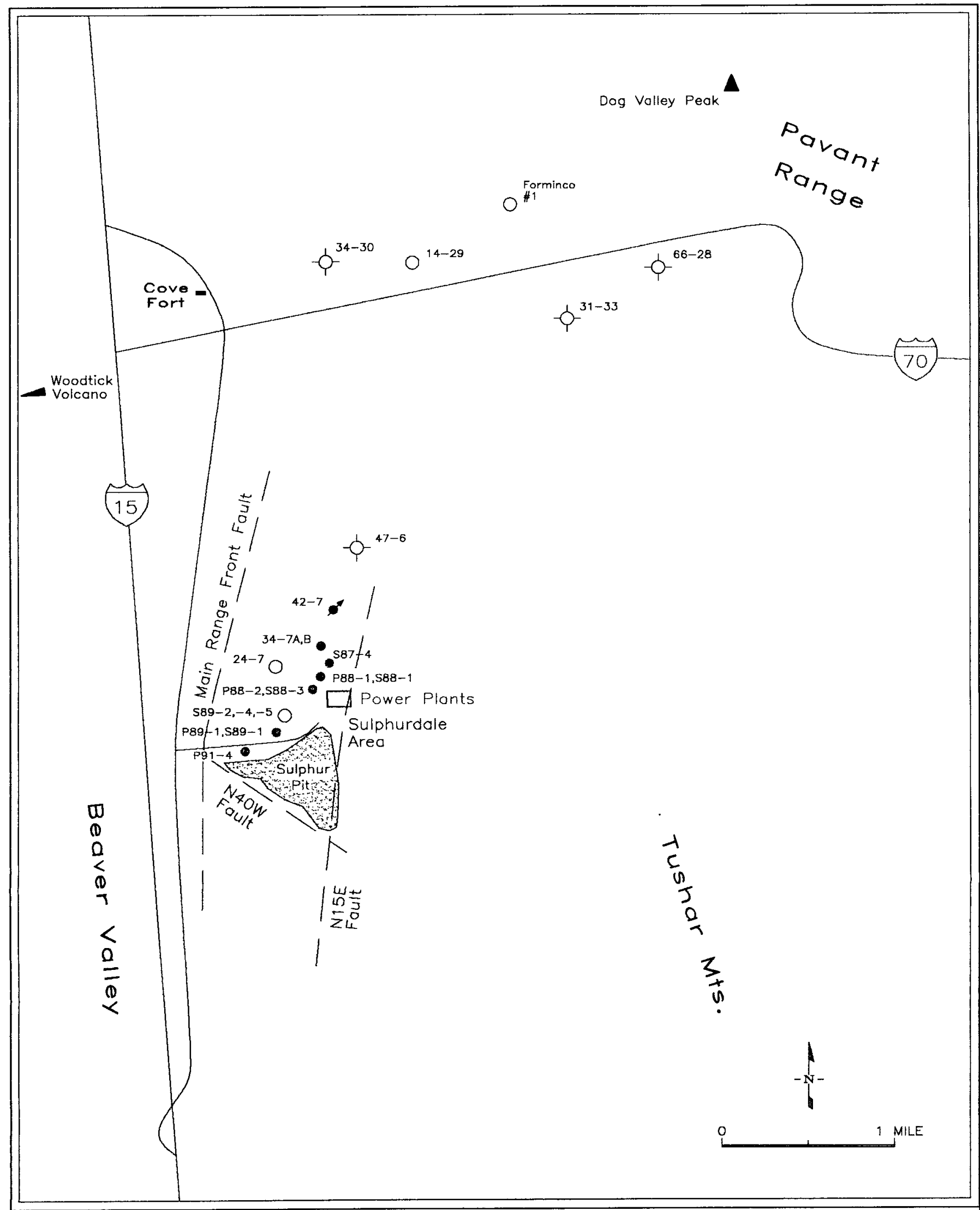

\section{LEGEND}

- Production well

- Injection well

O Other well

- - - P \& A well
Figure 2.16: Well location map, Cove Fort geothermal field, Utah (after Huttrer, 1992)
GeothermEx, Inc.

GEOTHERMAL EXPLORATION DEVELOPMENT AND OPERATIONS 5221 Central Ave., Sulte 201, Richmond, CA 94804 (510) 527-9876 


\section{R9W}

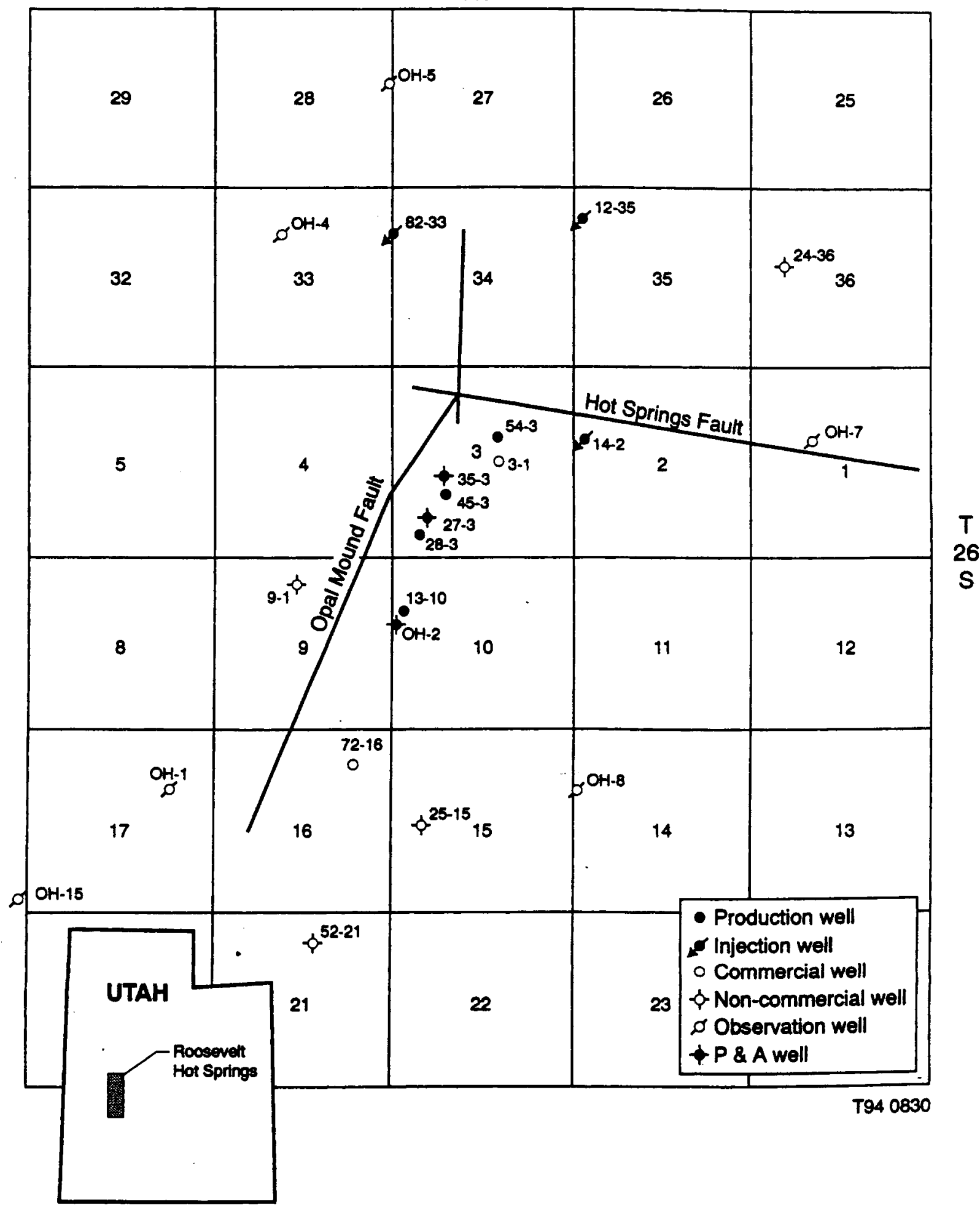

Figure 2.17: Well location map, Roosevelt geothermal field, Utah 
TELEPHONE: (510) 527-9876

FAX: (510) 527-8164

E-MAIL: GEOTHERMEX @COMPUSERVE.COM 


\section{ENHANCED GEOTHERYLAL SYSTEMS STATE.HEYT OF WORK}

Princeton Economic Research Institute (PER) will play an integral sole in the day-io-day management of the national Enhanced Geothermal Systems (EGS) progran (both ongoing and furure work) and shaping the future EGS program with emphasis $c a$ teaming and greater industrial participation. PERI will manage the national Enhancec Ceochermal Systems (EGS) activities to oversee and/or implement recommendations by an incissty panel. The industry panel made several recommendations:

- unify managernent of all geothermal R\&D programs and incluce EGS elements with the unified program;

- convene a panel to formulate shor- and long-term geothermal $R \& D$ goals, including the long-term conmercialization of EGS;

- establish a peer-review committee to evaluate the current staris of the U.S. EGS program, publish its findings, and implement tectnology transfer to move EGS lochnology into the geothermal mainstream;

- coordinate U.S. geothermal R\&D efforts with EGS programs := ocher countries.

\section{TECANICAL TASKS}

All program direction will come from the Department of Energy, ¿isaho Operations Office (DOE. ID). PER shall work closely with DOE-ID to successfully perfor $=$ the following tasks:

- Develop EGS testing and researcts plans.

- Integrate EGS activities with industry needs for a balanced anci iñicient research program that is responsive to both industry (near-term) and DOE (longe:-ierm) needs.

- Serve as a focal point for integrating EGS projects into the ove:all geochermal R\&D program.

- Coordinate the efforts of a EGS peer-review committee, tasked with evaluating the current status of the U.S. EGS program.

- Propose cost-shared EGS research and development projects.

- Provide EGS program Research \& Development suppor

- Direct a panel of stakeholders to formulate short- and long-term geothermal R\&D goals, including the long-term commercialization of ECS.

- Review and evaluate new research tasks for scientific Eerit, technical feasibility and make recommendations to DOE on relevance to projeci goals and objectives.

- Collaborate with industry to develop an inventory of poiential EGS sites for development.

- Provide Technology Transfer Support

- Integrate EGS activities with industry needs for a balareced and efficient research program that is responsive to both industry (near-term) and DOE (longer-term) needs.

- Serve as a focal point for integrating EGS projects into the overall geothermal R\&D program. 
TASK ORDER NO. DE-ATO7-991060365

MODIFICATION AOOO

PAGE 3 OF 4

- Implement technology transfer efforts to move products and services developed under the EGS program to the geothermal mainstream.

- Conduct various workshops.

- Provide Tectrical Support

- Coordinate domestic and global EGS laboratory and field projects and report progress to interested stakeholders.

- Plan and conduct field tests relevant to EGS technology in cooperzcion with industriai partners.

- Periorm other tasks as necessary to support the mission of the EGS program

TASKS FOR FY'99

A. Program Management and Technical Support

Planning

- Provide Project Management

- Perform EGS Tactical Planning

- Review EGS Surategic Roadmap

- Provide EGS Program Technical Support

Evaluation \& Dissemination

- Prepare and Subonit Tecbnical Papers to World Geothernal Congress 2000

- Support DOE IEA Anmex II (EGS) Activities

- Plan, Organize, and Corduct EGS Program Review

B. EGS National Coordinating Committee

- Build Industry Support and Participation through the Committee

C. Tectnology Improvement (Component R\&D)

- Support EGS R\&D Solicitations

- Provide Preliminary Scoping for Baseline Technology Assessments

- Monitor Foreign EGS Research

- Coordinate with Advanced Drilling and Reservoir Technology R\&D

D. Development of Prototype

- Develop a Pilot Plant Scenario

- Collect and Review Information on Porential EGS Sites

\section{DELIVER+BLES}

PERI shall keep the Department currently advised by monthly status reports on the progress of all work. A full report on the tasks will be required upon the completion of tasks. Oral reports on matters of a critical nature shail be confirmed in writing at the earliest pracicable time.

\section{TRAYEL}

To support the mission of the EGS program, PERI will most likely travel to France, Japan, Germany, England, Australia, or other international sites, including support of ine Geothermal Implementing Agreement under the U.S. International Energy Agency Agreezent. 